\title{
Mycotoxin Biotransformation by Native and Commercial Enzymes: Present and Future Perspectives
}

\author{
Martina Loi ${ }^{1,2,+}$, Francesca Fanelli ${ }^{1, t, *}$, Vania C. Liuzzi ${ }^{1}$, Antonio F. Logrieco ${ }^{1}$ \\ and Giuseppina Mulè ${ }^{1}$ \\ 1 Institute of Sciences of Food Production, National Research Council, via Amendola 122/O, Bari 70126, Italy; \\ martina.loi@ispa.cnr.it (M.L.); vania.liuzzi@ispa.cnr.it (V.C.L.); antonio.logrieco@ispa.cnr.it (A.F.L.); \\ giuseppina.mule@ispa.cnr.it (G.M.) \\ 2 Department of Economics, University of Foggia, via Napoli 25, Foggia 71122, Italy \\ * Correspondence: francesca.fanelli@ispa.cnr.it; Tel.: +39-080-592-9317 \\ + These authors contribute equally to this work.
}

Academic Editor: Ting Zhou

Received: 31 January 2017; Accepted: 18 March 2017; Published: 24 March 2017

\begin{abstract}
Worldwide mycotoxins contamination has a significant impact on animal and human health, and leads to economic losses accounted for billions of dollars annually. Since the application of pre- and post- harvest strategies, including chemical or physical removal, are not sufficiently effective, biological transformation is considered the most promising yet challenging approach to reduce mycotoxins accumulation. Although several microorganisms were reported to degrade mycotoxins, only a few enzymes have been identified, purified and characterized for this activity. This review focuses on the biotransformation of mycotoxins performed with purified enzymes isolated from bacteria, fungi and plants, whose activity was validated in in vitro and in vivo assays, including patented ones and commercial preparations. Furthermore, we will present some applications for detoxifying enzymes in food, feed, biogas and biofuel industries, describing their limitation and potentialities.
\end{abstract}

Keywords: mycotoxins; biotransformation; degradation; enzymes; application

\section{Introduction}

Mycotoxins are secondary toxic metabolites produced by filamentous fungi mainly belonging to Fusarium, Aspergillus and Penicillium genera. They infect cereals, seeds and fruits both in the field and during storage, and can be found as common contaminants in food and feed supply chains [1,2].

Mycotoxins poisoning of staple food commodities has a significant impact on worldwide health, especially in developing countries [3,4]. Both animals and humans may develop acute and chronic mycotoxicosis, depending on several factors, which include the type of mycotoxin, the amount and the duration of the exposure, etc. Mycotoxins can be classified as hepatotoxins, nephrotoxins, neurotoxins, immunotoxins and so forth, based on the organ they affect [1]. Main target tissues include gastrointestinal and breathing apparatus, endocrine, exocrine, reproductive, nervous and immune system $[5,6]$. Aflatoxin $\mathrm{B}_{1}\left(\mathrm{AFB}_{1}\right)$ is the most toxic mycotoxin and has been classified in group 1, carcinogenic to humans, by the International Agency of Research on Cancer (IARC) in 2002 [7]. Other mycotoxins, such as aflatoxin $\mathrm{M}_{1}\left(\mathrm{AFM}_{1}\right)$, ochratoxin $\mathrm{A}(\mathrm{OTA})$ and fumonisin $\mathrm{B}_{1}\left(\mathrm{FB}_{1}\right)$, are classified within group $2 \mathrm{~B}$, thus possibly carcinogenic to humans, due to the limited availability of their toxicological data [7-9].

Synergistic and additive effects of different mycotoxins have been documented; however, the worsening and toxic outcome of multiple exposure cannot be predicted by summing up the 
individual toxicities. Furthermore, the mechanisms of interactions among toxins are still poorly understood [10]. In rats $\mathrm{FB}_{1}$ synergistically promotes liver lesions, hepatocyte dysplasia and, by long term exposure, tumors initiated by $\mathrm{AFB}_{1}[11]$. $\mathrm{AFB}_{1}$ also acts synergistically with zearalenone (ZEN) in decreasing egg production, feed intake, feed conversion ratio and eggshell strength in birds [12]. In vitro cytotoxicity of $\mathrm{AFM}_{1}$ on Caco-2 cells is greatly enhanced by the presence of OTA, ZEN and/or $\alpha$-zearalenol ( $\alpha$-ZEL), which often co-contaminate milk and infant formulas [13]. OTA and citrinin have often been reported to act in a synergistic mode in relation to their cytotoxic [14-17] and genotoxic effects [18].

Global trade significantly contributes to mycotoxin spread. The economic losses associated with mycotoxin contamination in commodities account for billions of dollars annually [19]. They can be categorized into direct and indirect losses: direct losses are related to lowered crop yields, reduction of animal performance and costs derived from diseases for livestock producers; indirect losses are very challenging to quantify, and are linked to the increased use of fungicide, the reduction of the marketable value of the commodities, the management, health-care, veterinary-care costs, and investments in the development of reducing strategies and in research programs.

Mycotoxins levels are regulated in many countries worldwide. The European Union has implemented the most extensive and detailed food regulation for mycotoxins within the Commission Regulation (EC) No. 1881/2006 [20], which set mycotoxins maximum levels discriminating among food products and consumers (e.g., adults or infants). Indicative levels in cereals and cereals products [21] have been established for the trichothecenes T-2 and HT-2 toxins (T-2, HT-2). A scientific opinion on their toxicity was released in 2001 by the European Commission Scientific Committee on Food (SCF) [22], highlighting the need for further studies on the occurrence, daily intake, analytical methods development and induced hematotoxicity and immunotoxicity. However, for other so-called emerging mycotoxins (e.g., enniatins, beauvericin, fusaric acid and moniliformin), whose increasing occurrence has been clearly evidenced, maximum levels have not been yet established. This delay exists since certified analytical methods for their determination, complete surveys on their occurrence and defined scientific opinions on their toxic effect and health associated risks are still being developed [21,23].

Mycotoxin contamination can be prevented in the field through the application of good agricultural practices (GAPs), such as the choice of resistant varieties, harvesting at the right time, crop rotation, and the use of fungicides [20,24]. Nevertheless, pre-harvest strategies are not completely effective, and fungal contamination of raw materials can lead to mycotoxin accumulation during storage. Furthermore, mycotoxins are extremely stable and resistant to the commonly used physical and chemical treatments of food and feed processing.

Since the application of GAPs, proper storage and risk management procedures might only mitigate mycotoxin occurrence, the development of alternative strategies to reduce mycotoxins contamination is considered a relevant, innovative, urgent, yet challenging research topic.

In this review, we will briefly present the current methods to reduce mycotoxins contaminations in food and feed, and then we will focus on the biotransformation of mycotoxins performed with purified enzymes isolated from bacteria, fungi and plants, whose activity was validated in in vitro and in vivo assays, including patented ones and commercial preparations. We will also describe enzyme potential applications and limitations in food, feed and bioenergy in compliance with the European Regulation.

\section{Methods for Mycotoxins Reduction}

Current methods to reduce mycotoxin contamination in food and feed can be classified into physical, chemical and biological. It must be underlined that EU regulation does not authorize any detoxification methods for those commodities, intended for food production, exceeding mycotoxins limit levels [20].

(1) Physical methods comprise the mechanical removal of highly contaminated fractions from raw materials (by sorting, cleaning, milling, dehulling), the application of heat, the irradiation and the use of adsorbents, which is still limited to feed production [25]. The latter approach is considered promising, 
although some possible negative drawbacks related to unspecific binding of essential nutrients and antibiotics exist. In addition, these adsorbents have diversified efficacy towards different classes of mycotoxins, with trichothecenes being the most difficult to target. Furthermore, since co-occurrence is much more common than individual contamination, complementary reduction strategies should be implemented.

Recently, the application of unconventional strategies such as cold plasma [26-28], photoirradiation [29,30] and microwave treatments [31] have been proposed and/or introduced in food processing, as sterilization or degrading methods. Nevertheless, the partial knowledge about degradation products (DPs) and the nutritional/organoleptic changes induced by these treatments still confine their application.

(2) Chemical methods such as ammoniation [32], acid treatments [33], alkaline hydrolysis [34], peroxidation [35], ozonation [36], and the use of bisulphites [37] have been tested, but their application in food and feed is limited due to their potential toxicity, poor efficacy, high costs and negative effects on the quality of raw materials.

(3) Biological methods consist of the use of microorganisms or enzymes, which are able to metabolize, destroy or deactivate toxins into stable, less toxic, up to harmless compounds [38]. Biological agents and their enzymes allow a specific, most likely irreversible, environmental friendly and effective approach, with minor impact on food sensory and nutritional quality with respect to chemical ones.

\section{Mycotoxin Biotransformation by Enzymes}

Mycotoxin biotransformation is defined as "the degradation of mycotoxins into non-toxic metabolites by using bacteria/fungi or enzymes" [39]. The possibility to use living microorganisms as whole cell biocatalysts for mycotoxins degradation has cost advantages. This represents a valid strategy, especially if multi step reactions are required, or if the microorganism is already implemented within industrial processes [40,41]. On the other hand, in case of high levels of mycotoxins contamination, the growth and physiology of such microorganisms might be altered or inhibited, thus requiring longer time for adaptation before achieving satisfactory decontamination levels.

The majority of the research papers which describes microbial degrading activity, rarely discriminates between physical adsorption and enzymatic degradation. This greatly complicates the identification of DPs and the evaluation of their toxicity. This knowledge is relevant in the evaluation of biotrasforming enzymes, especially since not every reaction leads to a real detoxification. Indeed, the metabolized mycotoxin can acquire greater toxic properties than the parent compound. This is the case, for example, of ZEN biotransformation performed in vivo by yeasts, which reduce the toxin to $\alpha$-ZEL, actually more estrogenic than ZEN [42].

The identification and characterization of a degrading enzyme (DE) can be challenging and time consuming, but it is a necessary step to understand the mechanism of degradation, towards its optimization and the development of mycotoxins reducing methods. Enzymes guarantee reproducible and homogeneous performances, with ease-of-handling, no risks of contamination and no safety concerns for operators compared to the use of living microorganisms.

Screening microbial population from different mycotoxin-contaminated environment is an efficient, fast and promising strategy to discover degrading microbes and activities [43-45], which could be enhanced by coupling advanced approaches, such as metagenomics or functional metagenomics.

In addition, genetic engineering enables to clone and express heterologous enzymes in bacterial, yeast, fungal and plant cells for massive, less expensive and less laborious productions. If no structural-functional data are available, enzyme efficiency, stability and tolerance to organic solvents can also be improved by computational approaches, aiming at targeted or combinatorial semi-rational mutagenesis.

Many enzymes have been reported to remove or reduce mycotoxin contamination both in vitro and in real matrices. Nonetheless, their application in feed is very limited, due to the lack of information 
about the potential toxic effects of generated products and their influence on nutritional quality of feed. These data are mandatory to be authorized as possible biotransforming agent in Europe [39].

Very few commercial biotransforming feed additives are available: Mycofix $^{\circledR}$, FUMzyme ${ }^{\circledR}$, Biomin ${ }^{\circledR}$ BBSH 797 and Biomin ${ }^{\circledR}$ MTV (Biomin Holding GmbH, Getzersdorf, Austria) are some examples, but only FUMzyme ${ }^{\circledR}$ exploits a purified enzyme, an esterase, to perform fumonisin degradation. Below we will discuss in details the biotransformation of the main mycotoxins by native and commercial enzymes.

\subsection{Aflatoxins}

The term aflatoxins (AFs) includes more than 20 fungal secondary metabolites produced by fungi belonging to Aspergillus genus [1]. They are classified into two main groups according to their chemical structure. The difurocoumarocyclopentenone group includes $\mathrm{AFB}_{1}$, aflatoxin $\mathrm{B}_{2}$, aflatoxin $\mathrm{B} 2 \mathrm{a}, \mathrm{AFM}_{1}$, aflatoxin $\mathrm{M}_{2}$, aflatoxin $\mathrm{Q}_{1}\left(\mathrm{AFQ}_{1}\right)$, and aflatoxicol (AFL), while the difurocoumarolactone group comprises aflatoxin $\mathrm{G}_{1}$, aflatoxin $\mathrm{G}_{2}$ and aflatoxin $\mathrm{G} 2 \mathrm{a}$ (Figure 1).

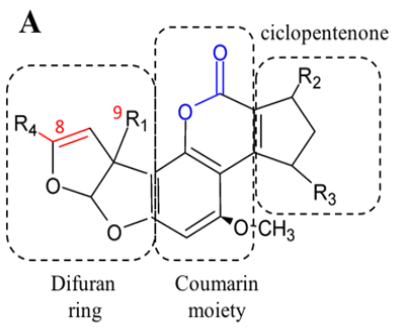

\begin{tabular}{cccccccc} 
& $\mathbf{A F B}_{1}$ & $\mathbf{A F B}_{2}$ & $\mathbf{A F B} \mathbf{a}$ & $\mathbf{A F M}_{\mathbf{1}}$ & $\mathbf{A F M}_{\mathbf{2}}$ & $\mathbf{A F L}$ & $\mathbf{A F Q}_{\mathbf{1}}$ \\
\hline $\mathrm{R} 1$ & $-\mathrm{H}$ & $-\mathrm{H}$ & $-\mathrm{H}$ & $-\mathrm{OH}$ & $-\mathrm{OH}$ & $-\mathrm{H}$ & $-\mathrm{H}$ \\
\hline $\mathrm{R} 2$ & $=\mathrm{O}$ & $=\mathrm{O}$ & $=\mathrm{O}$ & $=\mathrm{O}$ & $=\mathrm{O}$ & $-\mathrm{OH}$ & $=\mathrm{O}$ \\
\hline $\mathrm{R} 3$ & $-\mathrm{H}$ & $-\mathrm{H}$ & $-\mathrm{H}$ & $-\mathrm{H}$ & $-\mathrm{H}$ & $-\mathrm{H}$ & $-\mathrm{OH}$ \\
\hline $\mathrm{R} 4$ & $-\mathrm{H}$ & $-\mathrm{H}$ & $-\mathrm{OH}$ & $-\mathrm{H}$ & $-\mathrm{H}$ & $-\mathrm{H}$ & $-\mathrm{H}$ \\
\hline $\mathrm{C}_{8}-\mathrm{C}_{9}$ bond & unsaturated & saturated & saturated & unsaturated & saturated & unsaturated & unsaturated \\
\hline
\end{tabular}

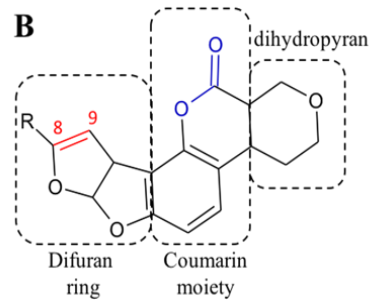

\begin{tabular}{cccc} 
& $\mathbf{A F G}_{1}$ & $\mathbf{A F G}_{2}$ & $\mathbf{A F G 2 a}$ \\
\hline $\mathrm{R}$ & $-\mathrm{H}$ & $-\mathrm{H}$ & $-\mathrm{OH}$ \\
\hline $\mathrm{C}_{8}-\mathrm{C}_{9}$ bond & unsaturated & saturated & saturated \\
\hline
\end{tabular}

Figure 1. Chemical structure and features of ciclopentenone (A) and difurocoumarolactone (B) aflatoxin (AF) series. Coloured bonds indicate reactive groups involved in AFs toxicity. The double bond leading to 8,9-epoxide upon metabolic activation is indicated in red, while the lactone bond is indicated in blue. Tables show substituent groups and saturation of the $\mathrm{C}_{8}-\mathrm{C}_{9}$ bond in different AF analogues.

While AFs of the B and G series co-occur in cereals and their derived products, fruits, oilseeds, nuts, tobacco and spices, $\mathrm{AFM}_{1} \mathrm{AFM}_{2}, \mathrm{AFL}$ and $\mathrm{AFQ}_{1}$ are detected in food as carry-over products of $\mathrm{AFB}_{1}$ contaminated feeds. In vivo $\mathrm{AFB}_{1}$ is readily metabolized through hydroxylation (to $\mathrm{AFM}_{1}$ or, to a lesser extent, to $\mathrm{AFQ}_{1}$ ) or reduction (to $\mathrm{AFL}$ ).

AFs are difuranocoumarin derivatives composed by two furan rings, linked together to a coumarin moiety. Furofuran and cumarin rings are arranged in a planar configuration which is responsible for conjugation leading to the typical AFs fluorescence.

The furofuran ring has been recognized as responsible for the toxic and carcinogenic activity upon metabolic activation of the $\mathrm{C}_{8}-\mathrm{C}_{9}$ double bond to 8-9 epoxide [9] (Figure 1).

The epoxidation is a crucial reaction for AFs carcinogenicity, since it allows the binding to N7-guanine and the subsequent G to T transversions in the DNA molecule [46]. Activated AFs are also able to form schiff bases with cellular and microsomal proteins (via methionine, histidine and lysine), thus leading to acute toxicity [47]. The lactone ring also plays a role in AFs toxicity and carcinogenicity: upon ammoniation it is hydrolyzed, forming aflatoxin $\mathrm{D}_{1}\left(\mathrm{AFD}_{1}\right)$ which still retains 
the 8,9-dihydrofuran double bond; $\mathrm{AFD}_{1}$ lacks the strong in vivo DNA binding activity of $\mathrm{AFB}_{1}$, demonstrating that DNA alkylation depends upon both difuranocumarin and lactone moieties [48].

Several authors addressed lactone hydrolysis, reduction or addition reactions as possible mechanisms of degradation, since the putative hydrolyzed products showed greatly reduced mutagenic activity in vitro $[49,50]$.

Table 1 summarizes the purified enzymes identified as capable of degrading AFs, and their main features. Although direct comparison is not possible, since the enzymes and the experimental conditions used by the authors are not equivalent, reaction parameters and AFs concentrations are indicated. 
Table 1. Aflatoxins (AFs) degrading enzymes.

\begin{tabular}{|c|c|c|c|c|c|c|c|c|}
\hline Enzyme & Accession/EC & $\begin{array}{l}\text { Producing } \\
\text { Organism }\end{array}$ & AF Target & $\begin{array}{c}\text { Toxin } \\
\text { Concentration }\end{array}$ & $\begin{array}{l}\text { In Vitro/In Matrix Degrading } \\
\text { Conditions }\end{array}$ & $\begin{array}{l}\text { In Vitro/In Matrix } \\
\text { Degradation }\end{array}$ & $\begin{array}{c}\text { Toxicity/Mutagenicity } \\
\text { Test }\end{array}$ & Reference \\
\hline $\begin{array}{l}\text { aflatoxin oxidase } \\
\text { enzyme (AFO) }\end{array}$ & EC 1.1 & $\begin{array}{l}\text { Armillariella } \\
\text { tabescens }\end{array}$ & $\mathrm{AFB}_{1}$ & $0.05 \mu \mathrm{g} / \mathrm{mL}$ & $\begin{array}{ll}\text { - } & \text { PBS buffer } 0.02 \mathrm{M} \mathrm{pH} 6 \\
\text { incubation at } 28^{\circ} \mathrm{C} \text { for } 30 \mathrm{~min}\end{array}$ & $\begin{array}{l}\text { - } \quad 100 \% \text { with } 0.2 \mathrm{mg} \text { of } \\
\text { enriched preparation; } \\
\text { - } \quad \mathrm{NQ}^{*} \text { with } \\
\text { pure enzyme }\end{array}$ & $\begin{array}{ll} & \text { reduced liver toxicity } \\
& \text { in rats; } \\
\text { - } & \text { reduced mutagenicity } \\
\text { in Salmonella } \\
\text { typhimurium TA 98; } \\
\text { - } \quad \begin{array}{l}\text { reduced genotoxicity } \\
\text { on chicken embryos }\end{array}\end{array}$ & [51] \\
\hline \multirow[b]{2}{*}{ peroxidase } & \multirow[b]{2}{*}{ EC 1.11.1.7 } & \multirow[b]{2}{*}{$\begin{array}{l}\text { horseradish } \\
\text { (Armoracia } \\
\text { rusticana) }\end{array}$} & \multirow[b]{2}{*}{$\mathrm{AFB}_{1}$} & $312 \mu \mathrm{g} / \mathrm{mL}$ & $\begin{array}{ll}\text { - } & \text { phosphate buffer } 50 \mathrm{mM} \mathrm{pH} \mathrm{6;} \\
\text { incubation at } 20^{\circ} \mathrm{C} \text { for } 60 \mathrm{~min}\end{array}$ & $42.2 \%$ & \multirow[b]{2}{*}{$\begin{array}{l}\text { reduced toxicity on Bacillus } \\
\text { megaterium }\end{array}$} & [52] \\
\hline & & & & $440 \mu \mathrm{g} / \mathrm{mL}$ & $\begin{array}{ll}\text { - } & 100 \mathrm{~g} \text { of defatted } \\
\text { groundnut kernels; } \\
\text { - } \quad \text { 2-16U of enzyme; } \\
50 \mathrm{mM} \text { phosphate buffer } \mathrm{pH} 6 \\
\text { and } 20 \mathrm{mM} \\
\quad \text { hydrogen peroxide; } \\
\text { incubation at room } \\
\text { temperature up to } 24 \mathrm{~h}\end{array}$ & $41.1 \%$ & & \\
\hline laccase & EC 1.10.3.2 & $\begin{array}{l}\text { Trametes versicolor } \\
\text { (commercial } \\
\text { enzyme from } \\
\text { Sigma-Aldrich, } \\
\text { Missouri, U.S.) }\end{array}$ & $\mathrm{AFB}_{1}$ & $1.40 \mu \mathrm{g} / \mathrm{mL}$ & $\begin{array}{l}\text {. } \quad \text { phosphate buffer } 0.2 \mathrm{M} \mathrm{pH} 6.5 \text {; } \\
\text {. } \quad \text { incubation anz } 30^{\circ} \mathrm{C} \text { for } 72 \mathrm{~h}\end{array}$ & $87 \%$ & $\begin{array}{l}\text { reduced mutagenicity on } \\
\text { Salmonella typhimurium } \\
\text { TA } 100\end{array}$ & [53] \\
\hline laccase & EC 1.10.3.2 & $\begin{array}{l}\text { Streptomyces } \\
\text { coelicor }\end{array}$ & $\mathrm{AFB}_{1}$ & $9.36 \mu \mathrm{g} / \mathrm{mL}$ & $\begin{array}{ll}\text { - } & \text { sodium acetate buffer } 100 \mathrm{mM} \\
& \mathrm{pH} 7 ; \\
\text { - } & 0.1 \mathrm{mg} / \mathrm{mL} \text { of enzyme protein } \\
& \text { and } 0.2 \mathrm{mM} \text { mediator; } \\
\text { - } \quad \text { incubation at } 37^{\circ} \mathrm{C} \text { for } 24 \mathrm{~h} \\
\end{array}$ & $100 \%$ & n.p. & [54] \\
\hline $\begin{array}{l}\text { F420H2-dependent } \\
\text { reductases }\end{array}$ & E.C. 1.5 .8 & $\begin{array}{l}\text { Mycobacterium } \\
\text { smegmatis }\end{array}$ & $\begin{array}{l}\mathrm{AFB}_{1} \\
\mathrm{AFB}_{2} \\
\mathrm{AFG}_{1} \\
\mathrm{AFG}_{2}\end{array}$ & n.p. & n.p. & n.p. & n.p. & [55] \\
\hline Mn peroxidase & EC 1.11.1.7 & Pleurotus ostreatus & $\mathrm{AFB}_{1}$ & $0.31 \mu \mathrm{g} / \mathrm{mL}$ & $\begin{array}{ll}\text { - } & \text { sodium lactate buffer } 50 \mathrm{mM} \\
& \mathrm{pH} 4.5 ; \\
\text { - } & 1.5 \mathrm{U} / \mathrm{mL} \text { of enzyme } \\
\text { - } & \text { incubation at } 30^{\circ} \mathrm{C} \text { for } 48 \mathrm{~h}\end{array}$ & $90 \%$ & n.p. & [56] \\
\hline $\begin{array}{l}\text { aflatoxin } \\
\text { degradation } \\
\text { enzyme }\end{array}$ & n.p. & Pleurotus ostreatus & $\mathrm{AFB}_{1}$ & $5 \mu \mathrm{g} / \mathrm{mL}$ & $\begin{array}{l}\text { - } \quad \text { sodium acetate buffer } 0.1 \mathrm{M} \\
\text { pH } 5 \text {; } \\
\text { - incubation at } 25^{\circ} \mathrm{C} \text { for } 1 \mathrm{~h}\end{array}$ & n.q. & n.p. & [50] \\
\hline
\end{tabular}


Table 1. Cont.

\begin{tabular}{|c|c|c|c|c|c|c|c|c|}
\hline Enzyme & Accession/EC & $\begin{array}{l}\text { Producing } \\
\text { Organism }\end{array}$ & AF Target & $\begin{array}{c}\text { Toxin } \\
\text { Concentration }\end{array}$ & $\begin{array}{l}\text { In Vitro/In Matrix Degrading } \\
\text { Conditions }\end{array}$ & $\begin{array}{l}\text { In Vitro/In Matrix } \\
\text { Degradation }\end{array}$ & $\begin{array}{c}\text { Toxicity/Mutagenicity } \\
\text { Test }\end{array}$ & Reference \\
\hline \multirow{3}{*}{$\begin{array}{l}\text { myxobacteria } \\
\text { aflatoxin } \\
\text { degrading } \\
\text { enzyme (MADE) }\end{array}$} & \multirow{3}{*}{ n.p. } & \multirow{3}{*}{$\begin{array}{l}\text { Myxococcus fulvus } \\
\text { ANSM068 }\end{array}$} & $\mathrm{AFB}_{1}$ & \multirow{3}{*}{$0.1 \mu \mathrm{g} / \mathrm{mL}$} & \multirow{3}{*}{$\begin{array}{ll}\text { - } & \text { citrate phosphate buffer } 0.1 \mathrm{M} \\
& \mathrm{pH} 6 ; \\
\text { - } & 100 \mathrm{U} / \mathrm{mL} \text { of enzyme } \\
\text { - } & \text { incubation at } 30^{\circ} \mathrm{C} \text { for } 48 \mathrm{~h}\end{array}$} & $72 \%$ with culture filtrates & \multirow{3}{*}{ n.p. } & \multirow{3}{*}{ [57] } \\
\hline & & & $\mathrm{AFG}_{1}$ & & & $97 \%$ & & \\
\hline & & & $\mathrm{AFM}_{1}$ & & & $96 \%$ & & \\
\hline \multirow{2}{*}{ laccase (lac2) } & \multirow{2}{*}{ EC 1.10.3.2 } & \multirow{2}{*}{$\begin{array}{c}\text { Pleurotus } \\
\text { pulmonarius } \\
\text { (ITEM 17144) }\end{array}$} & $\mathrm{AFB}_{1}$ & $1 \mu \mathrm{g} / \mathrm{mL}$ & \multirow{2}{*}{$\begin{array}{l}\text { - } \quad \text { sodium acetate buffer } 1 \mathrm{mM} \\
\mathrm{pH} 5 ; \\
\text { - } 5 \mathrm{U} / \mathrm{mL} \text { enzyme and } \\
\text { redox mediator; } \\
\text { - } \\
\text { incubation at } 25^{\circ} \mathrm{C} \text { for } 72 \mathrm{~h}\end{array}$} & $90 \%$ & \multirow{2}{*}{ n.p. } & \multirow{2}{*}{ [58] } \\
\hline & & & $\mathrm{AFM}_{1}$ & $0.05 \mu \mathrm{g} / \mathrm{mL}$ & & $100 \%$ & & \\
\hline \multirow{2}{*}{ Ery4 } & \multirow{2}{*}{$\begin{array}{c}\text { CAO79915.1/EC } \\
1.10 .3 .2\end{array}$} & \multirow{2}{*}{$\begin{array}{l}\text { Pleurotus eryngii } \\
\text { (PS419) }\end{array}$} & \multirow{2}{*}{$\mathrm{AFM}_{1}$} & \multirow{2}{*}{$0.05 \mu \mathrm{g} / \mathrm{mL}$} & $\begin{array}{ll}\text { - } & \text { sodium acetate buffer } 1 \mathrm{mM} \\
& \mathrm{pH} 5 ; \\
\text { - } & 5 \mathrm{U} / \mathrm{mL} \text { enzyme and } \\
& \text { redox mediator; } \\
\text { - } & \text { incubation at } 25^{\circ} \mathrm{C} \text { for } 72 \mathrm{~h}\end{array}$ & \multirow{2}{*}{$100 \%$} & \multirow{2}{*}{ n.p. } & \multirow{2}{*}{ [59] } \\
\hline & & & & & $\begin{array}{l}\text { artificially spiked skim } \\
\text { UHT milk; } \\
\text { - } 5 \mathrm{U} / \mathrm{mL} \text { enzyme and } \\
\text { redox mediator; } \\
\text { - } \quad \text { incubation at } 25^{\circ} \mathrm{C} \text { for } 72 \mathrm{~h}\end{array}$ & & & \\
\hline
\end{tabular}

n.q. = not quantitative; $n . p .=$ not provided. 
Most of these enzymes are comprised in the oxidoreductase (EC 1) group. The first identified was the AF oxidase enzyme (AFO) isolated from the edible fungus Armillariella tabescens by Liu and colleagues in 1998 [51]. AFO is an oxygen dependent reductase, releasing $\mathrm{H}_{2} \mathrm{O}_{2}$ as by product [51,60]. One $\mathrm{mg} / \mathrm{mL}$ of enriched preparation and $30 \mathrm{~min}$ of incubation at $28^{\circ} \mathrm{C}$ were needed to completely degrade $150 \mathrm{ng}$ of $\mathrm{AFB}_{1}$. $\mathrm{AFO}$ did not affect $\mathrm{AFB}_{1}$ fluorescence properties, indicating that the conjugation system, between the coumarin moiety and the lactone ring, was not disrupted by the degrading reaction. The mechanism proposed by the authors consisted of the enzymatic cleavage of the bisfuran ring. This hypothesis, although not yet experimentally verified, is in agreement with the reduced mutagenicity, toxicity and genotoxicity of the DPs and with their differential pulse voltammetry response similar to furofuran analogs [61,62]. Products of AFO treatment were found to exert neither liver toxicity in rats, nor mutagenicity activity on Salmonella typhimurium TA98, and not to be genotoxic to chicken embryos [61].

Three different peroxidases (EC 1.11.1.7) were also reported to possess $\mathrm{AFB}_{1}$ degrading capabilities. They were extracted and purified from horseradish (Armoracia rusticana) [52], Phanerochaete sordida YK-624 [63] and Pleurotus ostreatus [56]. The horseradish peroxidase was tested in vitro towards $\mathrm{AFB}_{1}$, which was reduced by $42 \%$ after $1 \mathrm{~h}$ with $0.2 \mathrm{U} / \mathrm{mL}$ of enzyme. Similar results were also obtained in real matrix: $\mathrm{AFB}_{1}$ was reduced by $41 \%$ in artificially spiked groundnut [64]. A lowered toxicity of the DPs was also registered by inhibition growth assay on Bacillus megaterium [51]. The two manganese peroxidases (MnPs) from the two different white rot fungi were studied $[56,63]$ in in vitro assays with similar reaction conditions, allowing a direct comparison. They were tested towards $0.3 \mu \mathrm{g} / \mathrm{mL}$ of $\mathrm{AFB}_{1}$, achieving $86 \%$ reduction after $24 \mathrm{~h}$ of incubation, and up to $90 \%$ after $48 \mathrm{~h}$ by using the $\mathrm{MnP}$ from P. sordida $Y K-624$ and the one from P. ostreatus respectively. Wang and colleagues [63] also registered $69.2 \%$ reduction of mutagenicity of DPs compared to $\mathrm{AFB}_{1}$, based on the umu test performed on Salmonella typhimurium TA1535 and on S9 liver homogenate. According to Proton Nuclear Magnetic Resonance $\left({ }^{1} \mathrm{H}-\mathrm{NMR}\right)$ and high resolution electrospray ionization mass spectrometry (HR-ESI-MS) analysis, the authors hypothesized that $\mathrm{MnP}$ treatment converted $\mathrm{AFB}_{1}$ to $\mathrm{AFB}_{1}-8$,9-dihydrodiol.

Laccases (EC 1.10.3.2) (LCs) have been intensively used in bioremediation [65] and were recently proposed for ZEN and AFs biotransformation [59,66,67].

Alberts and colleagues [53] made as firsts a decisive step towards the correlation between AFs degradation and LCs activity. The authors used different LCs, including native LCs from representatives of Peniophora genus and P. ostreatus, one commercial LC from Trametes versicolor, and one recombinant LC from Aspergillus niger. By treatment with $1 \mathrm{U} / \mathrm{mL}$ of the commercial preparation $\mathrm{AFB}_{1}(1.4 \mu \mathrm{g} / \mathrm{mL})$ was reduced by $87.34 \%$ after 3 days of incubation at $30^{\circ} \mathrm{C}$. DPs were not identified, but proved to be less mutagenic than the parent compound. However, none of the preparations used by the authors was purified to homogeneity. The commercial product from $T$. versicolor was indeed an enriched preparation, which included additional proteins and different laccase isoforms [68]; thus, an unambiguous assignment of the degrading activity to a specific LCs would be improper.

Recently the effectiveness of purified LCs towards AFs and ZEN was acknowledged $[58,67,68]$. Pure LCs from P. pulmonarius and P. eryngii were used by Loi and colleagues [58,59] towards both $\mathrm{AFB}_{1}$ and $\mathrm{AFM}_{1}$. The authors performed in vitro and in matrix tests with $1 \mu \mathrm{g} / \mathrm{mL}$ of $\mathrm{AFB}_{1}$ and $0.05 \mu \mathrm{g} / \mathrm{mL}$ for $\mathrm{AFM}_{1}$. Interestingly, they reported that, while LC alone is poorly able to degrade these toxins, the addition of a redox mediator at $10 \mathrm{mM}$ concentration increased the degrading percentages from $23 \%$ up to $90 \%$ for $\mathrm{AFB}_{1}$, and up to $100 \%$ for $\mathrm{AFM}_{1}$ after $72 \mathrm{~h}[58,59]$.

The laccase-mediator approach patented by Novozymes in 2008 [54], consisted of the use of LCs, preferably from Streptomyces coelicolor, and methylsyringate as mediator. In this case, $\mathrm{AFB}_{1}$ was completely removed after $24 \mathrm{~h}$ of incubation with $0.1 \mathrm{mg} / \mathrm{mL}$ of enzyme and $0.2 \mathrm{mM}$ of mediator at $37^{\circ} \mathrm{C}$.

Members of the reductase family have also been studied for AFs degrading capabilities. Among these, the F420H2-dependent reductases (EC 1.5.8.), isolated from Mycobacterium smegmatis, were tested 
towards $\mathrm{AFB}_{1}, \mathrm{AFB}_{2}, \mathrm{AFG}_{1}$ and $\mathrm{AFG}_{2}$; no details were provided in relation to efficacy and assay conditions [55].

Besides oxidases above described, Guan et al. [69] identified the myxobacteria aflatoxin DE (MADE), isolated from Myxococcus fulvus, which was further characterized in 2011 [57]. Pure MADE $\left(100 \mathrm{U} / \mathrm{mL}\right.$ ) was tested towards $0.1 \mu \mathrm{g} / \mathrm{mL}$ each of $\mathrm{AFG}_{1}$ and $\mathrm{AFM}_{1}$, achieving 98 and $97 \%$ of degradation after $48 \mathrm{~h}$ of incubation. No further details about the nature of the enzyme, nor about the DPs were given.

\subsection{Ochratoxin $A$}

OTA is a phenylalanine-dihydroisocoumarine derivative, composed of a 7-carboxy-5-chloro-8hydroxy-3,4-dihydro-3-R-methylisocoumarin (ochratoxin $\alpha-\mathrm{OT} \alpha$ ) moiety and a L- $\beta$-phenylalanine molecule (Phe), which are linked at the 7-carboxy group by an amide bond (Figure 2).

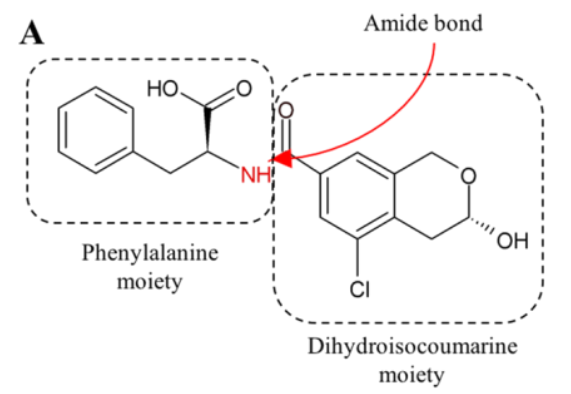

B

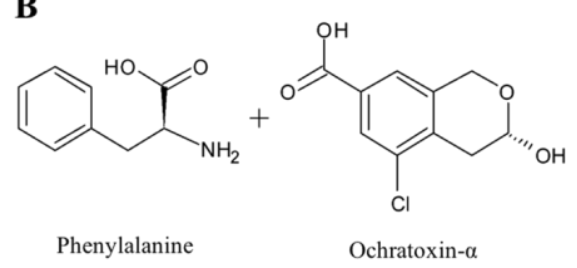

Figure 2. Chemical structures of (A) ochratoxin A and (B) its degradation products, ochratoxin- $\alpha$ and phenylalanine. The amide bond hydrolyzed by the main degrading pathway is indicated in red.

Due to its structural analogy to the amino acid Phe, the toxin can competitively inhibit tRNA phenylalanine synthetases and, consequently, block protein synthesis [70]. Furthermore, OTA causes the formation of DNA adducts, indirect oxidative DNA damage and activates a network of interacting epigenetic mechanisms [71,72].

The main OTA detoxification pathway consists in the hydrolysis of the amide bond between the isocoumarin residue and phenylalanine, resulting in the formation of Phe and OT $\alpha$ (Figure 2). The former is considered to be a non-toxic compound, with a 10-times shorter elimination half-life than OTA [73].

Numerous enzymes were hypothesized to hydrolyze the OTA amide bond, but only few of them were isolated and characterized [74].

Two classes of carboxypeptidases (EC 3.4) have been associated with OTA degradation: carboxypeptidase A (CPA) and carboxypeptidase Y (CPY) class. CPA uses one zinc ion within the protein for hydrolysis (EC 3.4.24), while CPY is a serine-type carboxypeptidase (EC 3.4.16) and does not contain any zinc ion in its active site. The first peptidase reported as able to hydrolyze OTA was a $\mathrm{CPA}$ isolated from bovine pancreas, which resulted able to perform the degrading reaction with a $\mathrm{Km}$ value of $1.5 \times 10^{-4} \mathrm{M}$ at $25^{\circ} \mathrm{C}$ [75]. A CPY isolated from Saccharomyces cerevisiae was demonstrated to hydrolyze OTA with optimum at $\mathrm{pH} 5.6$ and $37^{\circ} \mathrm{C}$; its specific activity was very low considering that only $52 \%$ of OTA was converted into OT $\alpha$ after five days of incubation [74]. The same enzyme was efficiently immobilized on electroactive surfaces in order to develop a biosensor system for the direct 
detection of OTA in olive oil, with promising results [76]. Many carboxypeptidases have high optimal reaction temperatures $\left(30^{\circ} \mathrm{C}\right.$ or higher); this might not hamper detoxifying applications for food and feed [25].

Other enzymes are also able to perform OTA hydrolysis, such as lipases (EC 3.1), amidases (EC 3.5) and several commercial proteases (EC 3.4) [77-79].

By screening different commercial hydrolases, a lipase preparation from Aspergillus niger (Amano A) was shown to hydrolyze OTA into OT $\alpha$ and Phe. Single-step purification, by anion exchange chromatography, allowed the isolation of the pure protein. The lipase nature of the enzyme was confirmed by assaying the cleavage of p-nitrophenyl palmitate. The purified enzyme resulted able to completely hydrolyze $50 \mu \mathrm{g}$ of OTA into OT $\alpha$ after $120 \mathrm{~min}$ of incubation, in $1 \mathrm{ml}$ of reaction mixture [77].

Several commercial proteases were also reported to hydrolyze OTA to OT $\alpha$, such as Protease A from $A$. niger and pancreatin from porcine pancreas. These enzymes showed a significant hydrolytic activity at pH 7.5, which resulted in the cleavage of $87.3 \%$ and $43.4 \%$ of $1 \mu \mathrm{g}$ of OTA respectively, after $25 \mathrm{~h}$ of incubation in $1 \mathrm{ml}$ reaction mixture [78].

Finally, an amidase and the feed or food additive comprising it, capable of degrading OTA, were patented by Dalsgaard et al. in 2010 [79]. The protein, named amidase 2, is encoded by an open reading frame of A. niger. The degrading assay was performed in $300 \mu \mathrm{L}$ of reaction mixture, containing $160 \mathrm{ng} / \mathrm{mL}$ amidase 2 and $50 \mu \mathrm{g} / \mathrm{mL}$ of OTA. This enzyme was able to reduce OTA concentration by $83 \%$. Amidase 2 was tested also in some food preparations. The patented additive decreased OTA content, from $47 \mathrm{ppb}$ to undetectable level ( $<2 \mathrm{ppb})$, after $2.5 \mathrm{~h}$-incubation in contaminated milk. Similarly, OTA concentration in corn flour was reduced from $38 \mathrm{ppm}$ to less than $2 \mathrm{ppb}$ after $20 \mathrm{~h}$ of incubation.

\subsection{Fumonisins}

Fumonisins are a group of mycotoxins associated with several mycotoxicoses, including equine leukoencephalomalacia, porcine pulmonary edema and experimental kidney and liver cancer in rats [80]. Chemically, fumonisins are diesters of propane-1,2,3-tricarboxylic acid and similar long-chain aminopolyol backbones. Structurally they resemble the sphingoid bases sphinganine (SA) and sphingosine (SO), with tricarboxylic acid groups added at the $\mathrm{C}_{14}$ and $\mathrm{C}_{15}$ positions (Figure 3). This structural similarity is responsible for the fumonisin mechanism of action. It was described to act by disturbing the sphingolipids metabolism, by inhibiting the enzyme ceramide synthase, and leading to accumulation of sphinganine in cells and tissues [81-83].

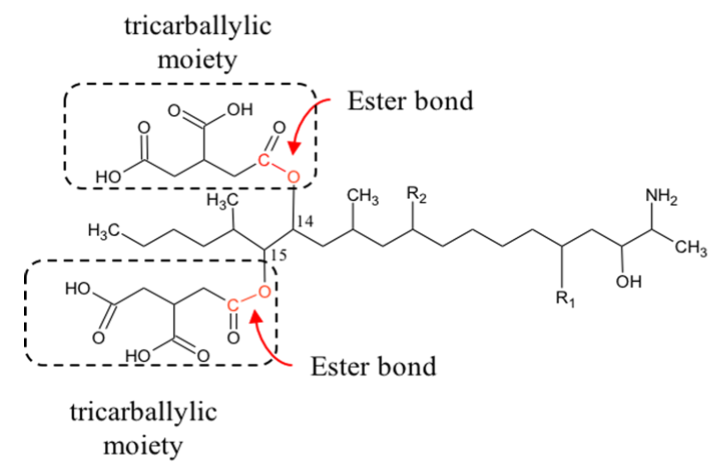

\begin{tabular}{ccccc} 
& $\mathbf{B}_{\mathbf{1}}$ & $\mathbf{B}_{\mathbf{2}}$ & $\mathbf{B}_{\mathbf{3}}$ & $\mathbf{B}_{\mathbf{4}}$ \\
\hline $\mathrm{R} 1$ & $-\mathrm{OH}$ & $-\mathrm{OH}$ & $-\mathrm{H}$ & $-\mathrm{H}$ \\
\hline $\mathrm{R} 2$ & $-\mathrm{OH}$ & $-\mathrm{H}$ & $-\mathrm{OH}$ & $-\mathrm{H}$ \\
\hline
\end{tabular}

Figure 3. Type B fumonisins chemical structure. The ester bonds hydrolyzed by the main degrading pathways, leading to the formation of $\mathrm{HFB}_{1}$ and the two tricarballylic acid moieties, are indicated in red. The table shows substituent groups of different fumonisin analogues.

There are at least 28 different forms of fumonisins, designated as A-series, B-series, C-series, and P-series [84]. The B-series (FB) is the most abundant and important with respect to toxicity. 
Pre-harvest strategies to reduce fumonisins contamination are based on the bio-control of the spread of fumonisin-producing fungi. Post-harvest methods include the application of natural clay adsorbents during food processing. While they do not lead to a real detoxification of fumonisin $[85,86]$, different microorganisms were reported to transform these class of mycotoxins. Among them, only few enzymes have been identified, molecularly and biochemically characterized, and patented.

$\mathrm{FB}_{1}$ was reported to be degraded by the consecutive action of a carboxylesterase (EC 3.1.1) [87] and an aminotransferase (EC 2.6.1) [88,89] (Table 2).

By the deesterification action of the carboxylesterase, the two tricarballylic acid moieties are released, resulting in hydrolyzed $\mathrm{FB}_{1}\left(\mathrm{HFB}_{1}\right)$, also known as aminopentol 1 (AP1). After the oxidative deamination, $\mathrm{HFB}_{1}$ is converted to $N$-acetyl $\mathrm{HFB}_{1}$ and 2-oxo-12,16-dimethyl-3,5,10,14,15-icosanepentol hemiketal [88]. The action of these enzymes, isolated from Sphingomonas sp. ATCC 55552 [90], was worldwide patented in 1994 [89]. 
Table 2. Fumonisin $B_{1}$ degrading enzymes.

\begin{tabular}{|c|c|c|c|c|c|c|}
\hline Enzyme & Producing Organism & Accession/EC & Toxin Concentration & Degrading Conditions & Degradation & Reference \\
\hline $\begin{array}{l}\text { carboxylesterase and } \\
\text { aminotransferase }\end{array}$ & $\begin{array}{l}\text { Sphingomonas sp. } \\
\text { ATCC55552 }\end{array}$ & E.C. 3.1.1, E.C. 2.6 .1 & $1000 \mu \mathrm{g} / \mathrm{mL}$ & $\begin{array}{l}\text { - } \quad \text { citrate buffer } 0.1 \mathrm{M} \mathrm{pH} 3 \text { or } \\
\text { citrate-phosphate buffer } 0.1 \mathrm{M} \mathrm{pH} 4 \text {; } \\
\text { - overnight incubation at } 37^{\circ} \mathrm{C}\end{array}$ & $100 \%$ & [89] \\
\hline $\begin{array}{l}\text { carboxylesterase B } \\
\text { and aminotransferase }\end{array}$ & $\begin{array}{l}\text { Sphingopyxis sp. } \\
\text { MTA144 }\end{array}$ & $\begin{array}{l}\text { E.C. 3.1.1, E.C. } 2.6 .1 / \\
\text { FJ426269.1 }\end{array}$ & $3.6 \mu \mathrm{g} / \mathrm{mL}$ & $\begin{array}{ll}\text { - } & \text { Tris- } \mathrm{HCl} 20 \mathrm{mM} \mathrm{pH} 8,0.1 \\
\mathrm{mg} / \mathrm{mL} \text { BSA; } \\
\text { - } \quad \text { incubation at } 30{ }^{\circ} \mathrm{C} \text { for } 2 \mathrm{~h}\end{array}$ & $100 \%$ & [80] \\
\hline fumonisin esterase & $\begin{array}{l}\text { Sphingopyxis sp. } \\
\text { MTA144 }\end{array}$ & E.C. 3.1.1.87 & $60 \mu \mathrm{g} / \mathrm{mL}$ & $\begin{array}{ll}\text { - } & \text { unspecified buffer } \mathrm{pH} 8 \\
\text { - } & 18 \mathrm{U} / \mathrm{L} \text { of enzyme } \\
\text { - } & \text { incubation at } 30^{\circ} \mathrm{C} \text { for } 15 \mathrm{~min}\end{array}$ & $\begin{array}{l}100 \% \\
\text { conversion } \\
\text { to } \mathrm{HFB}_{1}\end{array}$ & [91] \\
\hline
\end{tabular}


The same degrading activity was shown by Sphingopyxis sp. MTA144, isolated from composted earth [92]. In this strain the two key DEs were identified within a gene cluster: fumD, encoding a type B carboxylesterase, and fumI, encoding an aminotransferase $[80,93,94]$. The authors also demonstrated the degrading activities of the two recombinant enzymes by in vitro assays. The first enzyme, encoded by fumD, was able to catalyze the complete deesterification of $\mathrm{FB}_{1}(3.34 \mu \mathrm{g} / \mathrm{mL})$ to $\mathrm{HFB}_{1}$ within $15 \mathrm{~min}$. The oxygen independent aminotransferase, encoded by fumI, was shown to deaminate $\mathrm{HFB}_{1}(8.9 \mu \mathrm{g} / \mathrm{mL})$, in presence of pyruvate and pyridoxal phosphate, within $44 \mathrm{~h}$. Furthermore, the authors described the additional genes located in this putative degrading cluster identified by genome walking (NCBI Accession n. FJ426269). The cluster includes one transporter, one permease, dehydrogenases, and transcriptional regulators and was U.S. patented by Moll et al. within the "Method for the production of an additive for the enzymatic decomposition of mycotoxins, additive and use thereof" [95].

The esterase (EC 3.1.1.87) from Sphingopyxis sp. MTA144, produced by a genetically modified strain of Komagataella pastoris (formerly Pichia pastoris), has been included in a patented formulation, FUMzyme $^{\circledR}$ (Biomin Holding GmbH, Getzersdorf, Austria). This enzyme-based feed additive, whose safety and efficacy has been recently evaluated by EFSA [91], is intended to degrade fumonisins found as contaminants in feeds for growing pigs. The esterase partially degrades $\mathrm{FB}_{1}$ and related fumonisins by cleavage of the diester bonds and release of the tricarballylic acid.

\subsection{Trichothecenes}

Trichothecenes are a large group of sesquiterpenoid metabolites sharing a common core structure comprised in a rigid tetracyclic ring (Figure 4). To date, more than 190 trichothecenes and derivatives have been described $[96,97]$.

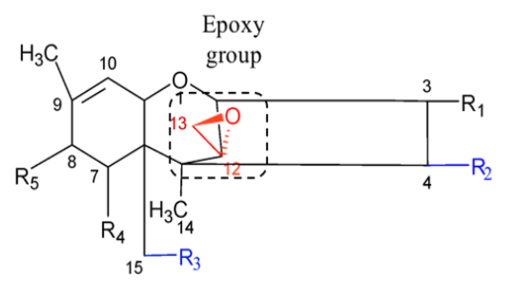

\begin{tabular}{ccccc} 
& T-2 & HT-2 & DON & NIV \\
\hline $\mathrm{R} 1$ & $-\mathrm{OH}$ & $-\mathrm{OH}$ & $-\mathrm{OH}$ & $-\mathrm{OH}$ \\
\hline $\mathrm{R} 2$ & $-\mathrm{OAc}$ & $-\mathrm{OH}$ & $-\mathrm{H}$ & $-\mathrm{OH}$ \\
\hline $\mathrm{R} 3$ & $-\mathrm{OAc}$ & $-\mathrm{OAc}$ & $-\mathrm{OH}$ & $-\mathrm{OH}$ \\
\hline $\mathrm{R} 4$ & $-\mathrm{H}$ & $-\mathrm{H}$ & $-\mathrm{OH}$ & $-\mathrm{OH}$ \\
\hline $\mathrm{R} 5$ & $-\mathrm{OCOCH}_{2} \mathrm{CH}\left(\mathrm{CH}_{3}\right)_{2}$ & $-\mathrm{OCOCH}_{2} \mathrm{CH}\left(\mathrm{CH}_{3}\right)_{2}$ & $=\mathrm{O}$ & $=\mathrm{O}$ \\
\hline
\end{tabular}

Figure 4. Chemical structure of trichothecenes. Groups responsible for trichothecenes toxicity are highlighted in red (epoxide) and blue (substituent groups, see the text for further details). The table shows substituent groups of different trichothecene analogues.

Their synthesis starts with the formation of trichodiene via the cyclization of farnesyl pyrophosphate. Trichodiene then undergoes a series of oxygenation, cyclizations, isomerization and esterification needed for the bioactivation of the molecule [98].

Trichothecenes are classified into 4 groups according to the functional groups associated to the core molecule: type A trichothecenes (e.g., T-2 and HT-2) do not contain a carbonyl group at the C-8 position; type $\mathrm{B}$ trichothecenes (mainly represented by deoxynivalenol (DON) and nivalenol (NIV) contain a carbonyl group at the C-8 position; trichothecenes of type $C$ (e.g., crotocin and baccharin) have an additional epoxy ring between $C-7$ and C-8, or between C-9 and C-10; trichothecenes of type D (e.g., satratoxin and roridin), contain a macrocyclic ring between C-4 and C-15 (Figure 4).

The results of trichothecenes exposure on eukaryotic cells was reviewed by Rocha et al. [99], while T-2 and HT-2 toxicity data were reported to EFSA in 2010 by Schuhmacher-Wolz and colleagues [100]. Trichothecenes are not degraded during normal food processing, they are stable at neutral and acidic $\mathrm{pH}$ and, consequently, they are not hydrolyzed in the stomach after ingestion [99]. 
Type A trichothecenes arise special interest, being more toxic than the other food-borne trichothecenes [101]. Among the effects exerted by T-2 and HT-2 toxins several studies reported the inhibition of DNA, RNA and protein synthesis, and apoptotic effects in mammalian cell cultures in vitro and ex vivo [22,102].

T-2 is rapidly metabolized to HT-2 in the gut. Data indicate that these toxins induce acute toxic effects with similar severity. For these reasons, the toxicity of T-2 in vivo is considered to include that of HT-2 [102]. Type B trichothecene have a relatively low toxicity compared to type A trichothecene, but it varies depending on the species and the cell type. The general toxic mechanism of trichothecenes is induced by the interference with protein synthesis, through 60S ribosome binding, leading to translation inhibition [103].

The 12,13-epoxy ring is the most important structural determinant of trichothecenes toxicity. In addition, the presence of hydroxyl or acetyl groups at appropriate positions on the trichothecene core [104], the presence of substituents on $C_{15}$ and $C_{4}[105,106]$, and of the side groups, are implicated in defining the degree of toxicity [107]. Both acetylation and de-acetylation may reduce toxicity of trichothecenes, as well as epimerization, oxidation [108-110].

Trichothecenes are noticeably stable molecules under different treatments, including both thermal and chemical ones. Several microorganisms, isolated from disparate complex environments, such as rumen or soil, have been reported to degrade trichothecenes into de-acetylated and/or de-epoxidated products [25]. However, the majority of the studies focused on this topic never achieved the identification of the enzymes responsible for the biotransformation. Nevertheless, considering the reaction products, acetylase, deacetylase or de-epoxidase activities are surely involved in the process.

In addition, hydroxylation and glycosylation of trichothecenes generate less toxic derivatives [111]. In this case, these compounds might undergo reverse reaction in the digestive tract of humans and animals, limiting the use of these enzymes at least in feed-related applications.

Recently, the bacterial cytochrome P450 system (EC 1.14) from Sphingomonas sp. strain KSM1, was reconstructed in vitro and demonstrated to hydroxylate DON, NIV and 3-acetyl DON [112] (Table 3). The system includes the cytP450, encoded by the gene ddnA, and the endogenous redox partners. The DON catabolic product, 16-HDON, is used by the Sphingomonas strain as a carbon source, and was shown to exert a reduced phytotoxicity to wheat.

Poppengberger et al. [113] identified a UDP-glycosyltransferase from Arabidopsis thaliana (the deoxynivalenol-glucosyl-transferase DOGT1) able to catalyze the transfer of glucose from UDP-glucose to the hydroxyl group at C3 of DON forming 3-O-glucopyranosyl-4-DON. The overexpression of this enzyme in $A$. thaliana enhanced DON resistance. The reaction products were identified by in vitro assays, using the enzyme purified from recombinant Escherichia coli cells.

Commercial products containing biotransformant agents have already been developed and patented. As an example, Biomin ${ }^{\circledR}$ BBSH 797 includes a pure culture of Eubacterium BBSH 797 isolated from bovine rumen fluid; it is capable of converting DON into DOM-1 and with de-epoxydase activity towards NIV, T-2, tetraol, scirpentriol, and HT-2. Nevertheless, purified enzymes with specific trichothecenes degrading activity have not been yet reported.

However, the recent increasing of microorganisms isolated from trichothecenes contaminated environments and capable of transforming this class of toxins led to the assumption that this goal will not be so distant $[109,110,114]$. 
Table 3. Trichothecenes degrading enzymes.

\begin{tabular}{|c|c|c|c|c|c|c|c|c|}
\hline Enzyme & Accession/EC & $\begin{array}{l}\text { Producing } \\
\text { Organism }\end{array}$ & $\begin{array}{l}\text { Trichothecene } \\
\text { Target }\end{array}$ & $\begin{array}{c}\text { Toxin } \\
\text { Concentration }\end{array}$ & Degrading Conditions & $\begin{array}{c}\text { In Vitro } \\
\text { Degradation }\end{array}$ & $\begin{array}{c}\text { Toxicity-Mutagenicity } \\
\text { Test }\end{array}$ & Reference \\
\hline \multirow[b]{2}{*}{$\begin{array}{c}\text { cytochrome P450 } \\
\text { system (Ddna + Kdx + } \\
\text { KdR) }\end{array}$} & \multirow[b]{2}{*}{$\begin{array}{l}\text { E.C. } 1.14 \\
\text { AB744215.1 } \\
\text { AB744217.1 }\end{array}$} & \multirow[b]{2}{*}{$\begin{array}{l}\text { Sphingomonas sp. } \\
\text { strain KSM1 }\end{array}$} & DON & $99.86 \mu \mathrm{g} / \mathrm{mL}$ & \multirow{2}{*}{$\begin{array}{l}\text { - } \quad \text { potassium phosphate buffer } 10 \\
\mathrm{mM} \mathrm{pH} 7.5 ; \\
10 \% \text { glycerol, } 0.2 \mu \mathrm{M} \text { DdnA, } 1.2 \\
\mu \mathrm{M} \mathrm{Kdx}, 1.2 \mu \mathrm{M} \mathrm{KdR}, 1 \mathrm{mM} \\
\mathrm{NADH} \text {, and } 100 \mathrm{mg} / \mathrm{ml} \text { bovine } \\
\text { liver catalase; } \\
\text { - overnight incubation at } 30^{\circ} \mathrm{C}\end{array}$} & $100 \%$ after 3 days & \multirow[b]{2}{*}{$\begin{array}{l}\text { reduced } \\
\text { phytotoxicity to } \\
\text { wheat }\end{array}$} & [112] \\
\hline & & & NIV & $105.25 \mu \mathrm{g} / \mathrm{mL}$ & & $100 \%$ after 5 days & & \\
\hline UDP-glycosyltransferase & AC006282 & $\begin{array}{l}\text { Arabidopsis } \\
\text { thaliana }\end{array}$ & DON & n.p. & n.p. & n.p. & $\begin{array}{l}\text { increased resistance } \\
\text { in transgenic } \\
\text { Arabidopsis }\end{array}$ & [113] \\
\hline
\end{tabular}

n.p. $=$ not provided 


\subsection{Zearalenone}

ZEN is a resorcylic acid lactone, nonsteroidal yet estrogenic mycotoxin, which binds to mammalian estrogen receptors (ER), although with lower affinity than the natural estrogens $17 \beta$-estradiol, estriol and estrone [115]. From a structural point of view, ZEN resembles the 17- $\beta$ estradiol, and this similarity is responsible for its estrogenic potential and ER binding capacity (Figure 5).
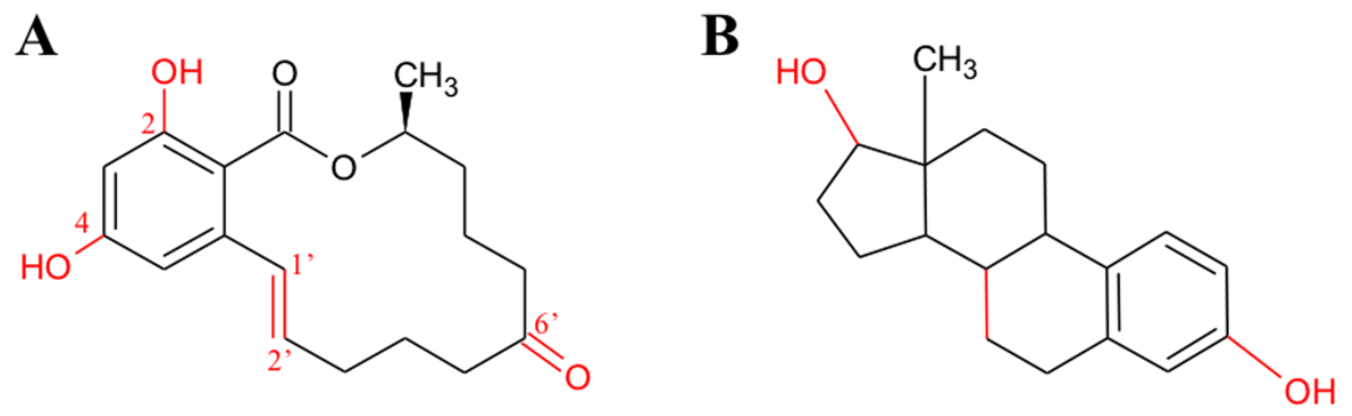

Figure 5. Chemical and structural analogies between zearalenone (A) and $17 \beta$-estradiol (B). The main chemical groups interacting with the estrogen receptors and responsible for zearalenone toxicity are highlighted in red (see the text for further details).

In vivo ZEN undergoes reduction to $\alpha$-ZEL and $\beta$-zearalenol ( $\beta$-ZEL), with the first being more estrogenic than the parent compound [116]. A further reduction leads to the formation of $\alpha$ - and $\beta$-zearalanol ( $\alpha$-ZAL, $\beta$-ZAL), which are both less estrogenic than ZEN.

ZEN estrogenicity is greatly enhanced by the reduction of the $6^{\prime}$-ketone group and of the $1^{\prime}-2^{\prime}$ double bond, while it is reduced by the methylation of the hydroxyls in $\mathrm{C} 4$ and $\mathrm{C} 2$. The $\mathrm{OH}$ group in $6^{\prime}$ of $\alpha$ and $\beta$-ZEL resembles that of C3 in estradiol. This group strongly interacts with ER, while the saturation of the $1^{\prime}-2^{\prime}$ double bond increases the flexibility of the molecule. This allows ZEN and/or ZEL to undergo some slight conformational changes, effective at adapting the molecules to the binding pocket of the receptor. Hydroxyl groups in $\mathrm{C} 4$ and $\mathrm{C} 2$ also contribute to the binding, with the first being more important than the latter in increasing ZEN estrogenic potential [116] (Figure 5).

ZEN and derivatives detoxification strategies aim at disrupting their estrogenic activity. Among the reported ZEN metabolizing reactions, lactone ring cleavage, catalyzed by esterases, is the prevalent detoxification method described so far. Since the resulting hydroxyketones spontaneously decarboxylate, the reaction is irreversible.

A lactonohydrolase (EC 3.1.1) from the fungus Clonostachys rosea has been identified as capable of degrading ZEN. The enzyme was purified to homogeneity, and its gene (namely zhd101) was cloned and characterized by heterologous expression in E. coli BL21 and S. cerevisiae INVSc1 $[117,118]$ (Table 4). The recombinant protein was proved to completely degrade $2 \mu \mathrm{g} / \mathrm{mL}$ of ZEN in in vitro assays, although with minimal yeast mediated conversion of ZEN to $\beta$-zearalenol. Zhd101 gene and transformants carrying lactonohydrolase gene were patented in 2002 [119]. 
Table 4. Zearalenone degrading enzymes.

\begin{tabular}{|c|c|c|c|c|c|c|c|}
\hline Enzyme & Producing Organism & EC & $\begin{array}{c}\text { Toxin } \\
\text { Concentration } \\
\end{array}$ & Degrading Conditions & Degradation & $\begin{array}{c}\text { Toxicity-Mutagenicity } \\
\text { Test }\end{array}$ & Reference \\
\hline laccase & $\begin{array}{l}\text { Trametes versicolor } \\
\text { (commercial enzyme } \\
\text { from Sigma-Aldrich) }\end{array}$ & EC 1.10.3.2 & $6.2 \times 10^{-4} \mu \mathrm{g} / \mathrm{mL}$ & $\begin{array}{l}\text { - } \quad \text { sodium acetate buffer } 0.2 \mathrm{M} \mathrm{pH} 5.2 ; \\
\text { incubation at } 30^{\circ} \mathrm{C} \text { for } 4 \mathrm{~h} .\end{array}$ & up to $58 \%$ & n.p. & [67] \\
\hline laccase & Streptomyces coelicolor & EC 1.10.3.2 & $9.36 \mu \mathrm{g} / \mathrm{mL}$ & $\begin{array}{ll} & \text { sodium acetate } 0.1 \mathrm{M} \mathrm{pH} 4.5 ; \\
& 0.2 \mathrm{mM} \text { mediator; } \\
& \text { incubation at } 37^{\circ} \mathrm{C} \text { for } 24 \mathrm{~h} \\
\end{array}$ & $100 \%$ & n.p. & [120] \\
\hline lactono hydrolase & Clonostachys rosea & E.C. 3.1 .1 & $2 \mu \mathrm{g} / \mathrm{mL}$ & $\begin{array}{ll}\text { - } & \text { YPD; } \\
\text { incubation at } 28^{\circ} \mathrm{C} \text { for } 4 \mathrm{~h} \text { or at } 37^{\circ} \mathrm{C} \text { for } \\
2 \mathrm{~h}\end{array}$ & $100 \%$ & n.p. & {$[117,118]$} \\
\hline \multirow{2}{*}{ 2cys-peroxiredoxin } & \multirow{2}{*}{ Acinetobacter sp. SM04 } & \multirow{2}{*}{ EC 1.11.1.15 } & $20 \mu \mathrm{g} / \mathrm{mL}$ & $\begin{array}{ll}\text { - } & \text { Tris- } \mathrm{HCl} 50 \mathrm{mM} \mathrm{pH} \mathrm{9;} \\
\text { - } & \mathrm{H}_{2} \mathrm{O}_{2} \geqslant 20 \mathrm{mM} ; \\
& \text { incubation at } 30^{\circ} \mathrm{C} \text { for } 4 \mathrm{~h}\end{array}$ & up to $95 \%$ & \multirow{2}{*}{$\begin{array}{l}\text { reduced MCF-7 cells } \\
\text { proliferation by } 75 \%\end{array}$} & \multirow{2}{*}{ [121] } \\
\hline & & & $1 \mu \mathrm{g} / \mathrm{mL}$ & $\begin{array}{l}\text { - } 1 \mathrm{~mL} \text { of } 0.8 \mathrm{M} \mathrm{H}_{2} \mathrm{O}_{2} \text { and } 19 \mathrm{~mL} \text { of } \\
\text { - } \quad \text { incubatiod recombinant } \mathrm{Prx} \text { solution } \mathrm{pH} 90^{\circ} \mathrm{C} \text { for } 6 \mathrm{~h} \text {. }\end{array}$ & up to $90 \%$ & & \\
\hline
\end{tabular}


Besides the above-mentioned activity towards AFs, laccases are also able to degrade ZEN. Novozyme patented the laccase-mediator degradation of ZEN in 2007 [120], using Streptomyces coelicolor LC and, preferably, phenotiazin-10-propionic acid or methylsyringate as redox mediators. By using this system, ZEN was completely removed by $0.1 \mathrm{mg} / \mathrm{mL}$ of LC and $0.2 \mathrm{mM}$ of mediator at $37^{\circ} \mathrm{C}$, within $24 \mathrm{~h}$. Laccase degrading capabilities were also studied by Banu and colleagues [67] using one LC-enriched Trametes versicolor preparation. Reactions, containing $6.2 \times 10^{-4} \mu \mathrm{g} / \mathrm{mL}$ of ZEN, were incubated with $0.4 \mathrm{mg} / \mathrm{mL}$ of laccase for $4 \mathrm{~h}$ at $30{ }^{\circ} \mathrm{C}$, achieving a maximum of $81.7 \%$ of degradation.

Another ZEN degrading oxidoreductase is a 2-Cys peroxiredoxin (Prx) (EC 1.11.1.15) extracted from Acinetobacter sp. SM04 [121,122]. Prxs are peroxidases containing redox-active cysteine, which can be oxidized to cystine by using $\mathrm{H}_{2} \mathrm{O}_{2}$ as cofactor. Prx degraded up to $95 \%$ of ZEN $(20 \mu \mathrm{g} / \mathrm{mL})$ in in vitro assays, when added with $20 \mathrm{mM} \mathrm{H}_{2} \mathrm{O}_{2}$; nearly $90 \%$ of the toxin was instead degraded in contaminated corn sample (ZEN levels of nearly $1000 \mu \mathrm{g} / \mathrm{mL}$ ), treated for $6 \mathrm{~h}$ at $30^{\circ} \mathrm{C}$ with purified recombinant Prx, plus $0.09 \%$ (mass fraction, $\mathrm{mol} / \mathrm{mol}$ ) $\mathrm{H}_{2} \mathrm{O}_{2}$. Toxicity bioassays were also performed. The proliferative effect on MCF-7 cells by ZEN-DPs was reduced by 75\%. Altalhi and colleagues [123] identified a $5.5 \mathrm{~kb}$ gene fragment from Pseudomonas putida pZEA-1, which encodes for DE(s) not yet characterized. E. coli DH5 cells, expressing the $5.5 \mathrm{~kb}$ gene fragment, were able to reduce $100 \mu \mathrm{g} / \mathrm{mL}$ of ZEN by $85 \%$ after $72 \mathrm{~h}$, while no degradation was observed by wild type cells. ZEN DPs were also shown to possess a marked reduced toxicity on Artemia salina larvae.

\section{Potentialities and Limitations of Mycotoxin Degrading Enzymes in Food, Feed, and Bioenergy}

The use of enzymes in the food, feed, biogas and biofuel industries is not new, as biocatalysts have been increasingly used in the last 30 years. They allowed reducing the employment of hazardous chemicals, to use mild working conditions, to increase specificity, to speed up a process or to simply create new products.

Enzyme biotechnological applications are widespread: the dairy industry has a long story of protease use for cheese manufacturing, while bakery employs laccase and transglutaminase to achieve doughs strengthening; phytases are used in non-ruminant animal nutrition for the degradation of phytic acid, which interferes with mineral absorption; pretreatment of lignocellulosic biomass for bioethanol production can be achieved using a cocktail of cellulases (endoglucanase, EC 3.2.1.4, exoglucanase, EC 3.2.1.91 and cellobiohydrolase, EC 3.2.1.21) instead of employing acid or alkali treatments $[124,125]$.

Mandatory requirements for enzyme application in large scale industry are (a) safety; (b) effectiveness; (c) low cost of production and purification for both enzyme and cofactors, if needed; d) stability to wide ranges of temperature, $\mathrm{pH}$ and organic solvents, and thus compatibility to productive processes. All those characteristics make the enzyme use advantageous from both technological and economic points of view. Native enzymes usually do not respond to each distinctive requirement of a perfect industrial enzyme, but these features can be achieved via molecular engineering and structure-function modifications by targeted or random mutagenesis.

The most important limitation related to the application of mycotoxin DEs in real matrices is represented by the reduced effectiveness of the process due to matrix effects. The physicochemical properties of food, such as the moisture and fat content, acidity, texture etc., greatly influence the success of the detoxification process. Moreover, inhibitory compounds may be present in raw materials and mycotoxins can occur in masked forms in plant tissues [126]; thus, their bioavailability for the enzyme catalysis may be further reduced. These implications might require pretreatments, additional time and costs, which must be taken into account in the development of industrial applications.

Despite these limitations, the potentialities of enzyme use in food and feed industries remain widespread. Their application is versatile, since they can be used both in free or immobilized form and easily applied to well established industrial processes (fermentations, ripening, brewing or cheese manufacturing, feed and bioenergy production). 
Moreover, DEs can be heterologously expressed by industrial microorganisms, such as lactic acid bacteria or yeasts, to perform in situ bioremediation. New smart and edible packaging with enzymes are also under study [127].

\subsection{Food}

The European Community established the last regulation on food enzymes in 2008 [128]. This regulation covers "enzymes added to food to perform a technological function in the manufacture, processing, preparation, treatment, packaging, transport or storage of such food, including enzymes used as processing aids". All enzymes are submitted to this regulation as processing aids, with the exception of lysozyme and invertase, considered as additives.

Article 6 states that necessary conditions to authorize a food enzyme are that (i) its use does not pose a safety concern for the health of the consumer; (ii) it responds to a technological need that cannot be achieved by other economically and technologically practicable means; and (iii) it does not mislead the consumer.

Only recently, acceptability criteria for detoxification treatments, including biotransformation, have been set for commodities intended for animal nutrition [38].

Some of the enzyme recognized to have mycotoxins degrading capabilities have been proposed and studied for applications in food industry, even if thought for other purposes.

Laccases have been studied for their introduction in bakery and dairy as crosslinking agent, in brewing, wine and fruit juice production as clarifying agent and polyphenol remover [129-131]. Peroxidases have also been studied for their crosslinking activity in bakery and dairy industry, but the use of $\mathrm{H}_{2} \mathrm{O}_{2}$ as cofactor limits their real application in food.

Amano enzyme Inc. (United Kingdom) requested EFSA to perform a scientific risk assessment on one laccase from Trametes hirsuta, currently in progress.

The employment of DEs in the food industry, especially in immobilized forms, is not unrealistic. Still, it must overcome the gap of knowledge related to the effects that these enzymes exert on the nutritional and organoleptic qualities of raw materials, as well as fill a legislative void, which, so far, does not foresee the possibility of detoxifying treatments for food.

\subsection{Feed}

Enzyme use in animal diets has a long history, starting from the 1920s, when a commercial enzyme preparation, produced by Aspergillus orizae, known as Protozyme, was applied in poultry diets [132]. Phytases, proteases, $\alpha$-galactosidases, glucanases, xylanases, $\alpha$-amylases, and polygalacturonases are commercially available and increasingly used in animal nutrition, with huge benefits in terms of nutritional value and micronutrients availability [133].

For authorizing their use in feed, EFSA requires solid supporting information about production, safety, efficacy and non-interference with the nutritional and organoleptic quality of the feed [134].

However, to become a commercial reality, an effective and safe DE must be formulated in order to guarantee its stability and efficacy during storage, and to ensure detoxification once released in the animal digestive tract.

There are two ways to apply a DE to feed: (a) as stabilized by a suitable formulation for becoming a feed additive or (b) used in a detoxifying process for contaminated raw materials intended for feed.

(a) During feed production enzymes are usually added before pelleting, in premixes with other additives (such as vitamins), or after pelleting as a liquid application. The most convenient approach is to introduce them as protected in formulations before pelleting: indeed, in this condition enzymes are less exposed to high moisture content and high temperature [135], thus preventing their inactivation.

High temperature protection is usually achieved by coating. Its challenging development has to succeed in both stabilizing the enzyme during feed processing, and in fast dissolving in the animal gut, thus releasing the active enzyme. To this aim new coated and tough (CT) granulated coatings have been developed by different companies (Novozymes ${ }^{\circledR}$, Bagsvaerd, Denmark; DSM ${ }^{\mathrm{TM}}$, The Netherlands). 
Within the CT granulates, enzymes are enclosed in a core matrix of minerals and carbohydrates. The outer layer can consist of vegetable oil, kaolin, and calcium carbonate, which are readily degraded upon ingestion [136]. On 5 May 2014 Biomin $^{\circledR}$ (Holding GmbH) received the first-ever EFSA positive opinion, for using a purified enzyme in feed. This is an esterase, embodied in a $10 \%$ maltodextrin matrix and spray dried, capable of biotransforming fumonisins.

(b) The development of a detoxifying application at industrial scale should allow the treatment of highly contaminated batches, with significant reduction of mycotoxin under the limits imposed by the current regulation. The achieved detoxification could result worthless in case of residual contamination by toxigenic fungi, if long term storage of the treated material is expected.

Free enzymes can be delivered in the feed productive process both in liquid and in solid forms (some prior wetting in dissolving feeders might be needed), through pumps, and mixed with the raw material, usually through a vertically mounted, shaft-driven impeller. This mode of application well fits a batch type process.

The major limitation of this approach is the difficulty to achieve a homogenous enzyme delivery throughout the entire material. In addition, the enzyme must target hot spots of contamination, typical of the distribution of toxigenic fungi and associated mycotoxins.

Among the environmental parameters that should be well set to preserve enzyme catalytic properties, moisture is by far the most critical. A high water content can increase enzyme activity, but simultaneously trigger fungal spread.

Immobilized enzymes encounter the same limitations, but they present the advantage of allowing the setup of continual processes, enzyme reuse and costs reduction.

\subsection{Bioenergy}

In biofuel production, enzymes are used to break down complex carbohydrates and to release ready fermentable sugars from cheap raw materials. Cellulose hydrolysis preceding fermentation is usually performed with cellulases, cellobiohydrolases and endoglucanases [137]. Pre-treatment of lignocellulosic biomasses prior to saccharification by laccases is under study, both to degrade lignin and to detoxify phenolic inhibitory compounds in bioethanol production $[138,139]$. The same biomass breakdown is realized during biogas production, especially in maize-feeded biogas plants, to adapt and accommodate raw materials and to enhance their suitability for the activity of methanogenic microorganisms [140,141]. In this case, the mixture may include cellulose, hemicellulose, pectin and starch DEs, but also proteins able to breakdown long chain fatty acids, whose accumulation is responsible for the decrease of the process stability.

Despite these applications, no enzymes have been yet developed to reduce mycotoxin level in maize silage, plants or any other substrate used for bioenergy production. Their content, which mirrors fungal contamination in raw materials, affects the efficiency of the anaerobic digestion and ethanol/methane accumulation: indeed, fungal metabolites, including mycotoxins, act as antimicrobial or inhibitory compounds, or lead to excessive foam formation [142].

Storm et al. [143] recently reviewed fungal and mycotoxin contamination in maize feeding biogas plants. The authors assessed that pre-harvest contamination of grass and maize by Fusarium spp., Aspergillus spp. and Alternaria spp. can lead to DON, ZEN, FBs and AFs accumulation, but with concentration usually lower than regulatory limits. Salati et al. [144] reported that the addition of $\mathrm{AFB}_{1}$ in a lab scale anaerobic digestion trials did not affect biogas production. In a recent conference abstract presented by De Gelder et al. [145] the authors evaluated the biodegradability of mycotoxins during anaerobic digestion. They performed lab scale degradation tests with digestate spiked with different mycotoxins. After 30 days of mesophilic and thermophilic digestion, each tested mycotoxin resulted absent in the final products, suggesting the activation of some adsorption/detoxification mechanism during the fermentation. The adsorption mechanism appears the most probable, since (1) as discussed in previous paragraphs mycotoxins are greatly stable and (2) they strongly bind to soil clay minerals 
and organic matter present in the reactors. However, no experiment has been performed in real biogas plants under conventional operating conditions.

Recent studies demonstrated that the addition of enzymes directly into biogas reactors has no significant effect on biogas process [146], since the enzymes are quickly degraded [147]. This obviously might require a continuous addition, and thus increases costs in comparison to raw materials pre-treatment. The development of enzymatic formulates able to couple biomass breakdown and mycotoxin degrading activity could allow the simultaneous increase of biogas yield and the safe utilization of byproducts, for which mycotoxins levels are not yet regulated.

The fate of mycotoxins during biofuel production has been only recently investigated. Dzuman et al. [148], performed a study on five different batches of the ethanol-distiller's grains and soluble (DDGS) production process. They reported a significant increase of deoxynivalenol and its glycosylated form, DON-3-glucoside, during the first part of fermentation, when hydrolytic enzymes were added. After yeast addition, total DON content rapidly decreased. They observed an opposite trend for $\mathrm{FB}_{1}$, since yeast addition contributed to its increase. The same results were discussed by Wu and Munkvold [149], who estimated that mycotoxins are concentrated up to three times in DDGS compared to the feeding grain.

Despite these data, the second generation of bioethanol industry is not greatly concerned by mycotoxin contamination since: (a) less susceptible commodities can be used as raw material; (b) mycotoxins occurrence in bioethanol byproducts is not yet regulated neither in Europe or in U.S. and (c) the growth and productivity of highly tolerant fermenting yeasts are only slightly influenced by mycotoxin contamination [150,151].

The re-use of contaminated biomasses for renewable energy production is raising great interest both for economic and environmental reasons. However, more detailed studies should evaluate side effects not sufficiently considered, since by-products use for animal nutrition in Europe, Canada and U.S. [152-155] is increasing.

Sosa et al. [156] performed a preliminary economic analysis evaluating the feasibility of using fumonisin highly contaminated corns as feedstock for ethanol production. The authors calculated that the advantages deriving from the lower price of contaminated raw materials is balanced by the increase of the operating costs and the decrease of the final ethanol production by the fermenter. Thus, the performance of the process must be optimized, using process alternatives (e.g., both microfiltration and pervaporation membranes) coupled by the introduction of ethanol tolerant yeast strains, in order to effectively increase the economic value of the process.

DDGS are considered valuable by-products, thanks to the low carbon-nitrogen ratio and their high proteins and micronutrients content [157]. However, their utilization should be responsibly addressed, since ecological outcomes of mycotoxin contaminated fertilizers and health effects are still poorly investigated.

As for biogas production, the implementation of DEs for biofuel application has not been developed. Still, it benefits of less limitations than those encountered by the food and feed industries. Cloning DEs in industrial hosts could ideally allow to simultaneously perform detoxification and fermentation of contaminated biomasses.

\section{Conclusions and Future Perspectives}

Within this review we gave a global view of the identified mycotoxins DEs, their mechanisms, their current and possible application in food, feed, biogas and biofuel industries. We also presented patented commercial preparations used by feed industries.

Although this paper is focused on the main mycotoxins, for which a high level of contamination and health implications have driven the majority of economic and research efforts, the discovery of novel DEs is becoming an interesting and stimulating topic also in relation to other mycotoxins.

Several patents have been deposited, mostly in U.S. and China, describing microorganisms and methods to degrade minor mycotoxins, such as patulin [158], beauvericin [159] and moniliformin [160] 
in plants, maize or grains. These patents are mainly related to microorganisms or crude extracts preparation, and no enzymes have been yet characterized as responsible for the degrading activity.

It should not be excluded that enzymes efficient towards minor mycotoxins could be effective towards structurally similar main ones.

In addition to the previously described ones, another challenge related to the application of DEs, is represented by mycotoxins co-occurrence, which should require the simultaneous use, and thus optimization, of different preparations and protocols. To overcome this barrier, the combination of different strategies, such as adsorbents mixture, binding microorganisms and enzymes, suitable for the inclusion within the same procedure, should be considered.

In the optimization process, great potentialities are ascribed to structural modelling and design of experiments (DOE) technologies. These approaches are able to identify structural determinants responsible for the degradation mechanism and to improve substrate-enzyme affinity by setting the conditions, which maximize enzyme efficiency. In combination with targeted mutagenesis methods, they strongly reduce lab-optimization processes and accelerate the industrial scale up.

Transcriptional analysis of degrading microorganisms [161] has recently led to the identification of a DE from the novel Acinetobacter sp. neg-1 species, described by Fanelli et al. [162] as capable of degrading OTA. This high-throughput approach, as other advanced Next Generation Sequencing technologies, such as functional metagenomic, could give a huge contribution in the identification of similar classes of DEs from complex and unexplored environments, such as contaminated soils, water or rumen. The advantage of these approaches is represented by the possibility to investigate non-culturable organisms, as well as those living in complex environmental niches, hardly analyzable under laboratory conditions.

The application of DEs could be simplified by the biotechnological advances in the field of immobilization and encapsulation techniques. Finally, an interesting perspective is represented by the development of transgenic crops able to counteract mycotoxins formation in the field. EU does not authorize the genetic modification of plants as a breeding technique. In contrast, the U.S. have 20 years of history of genetically engineered crops: herbicide-tolerant and insect-resistant crops were introduced in 1996 and today more than $90 \%$ of the corn cultivated in the U.S. is genetically modified [163].

Syngenta patented trichothecene-resistant transgenic plants bearing the Fusarium graminearum Tri101 gene [164], which encodes for a 3-O-acetyltransferase [165,166], which catalyzes the transfer of an acetate to the $\mathrm{C} 3$ position of trichothecenes. The company performed field trials, in Canada, the U.S., Argentina, and three European countries [108], proving that the development of self-defending crops is already achievable.

Acknowledgments: This work was financially supported by H2020-E.U.3.2-678781-MycoKey-Integrated and innovative key actions for mycotoxin management in the food and feed chain.

Author Contributions: M.L. and A.F.L. conceived the review. M.L., V.C.L. and F.F. performed the bibliographic research and wrote the paper. F.F. and G.M. coordinated the contributions. All authors reviewed the manuscript. F.F. was responsible for the submission.

Conflicts of Interest: The authors declare no conflict of interest.

$\begin{array}{ll}\text { Abbreviations } & \\ { }^{1} \mathrm{H}-\mathrm{NMR} & \text { Proton Nuclear Magnetic Resonance } \\ \mathrm{AFB}_{1} & \text { aflatoxin } \mathrm{B}_{1} \\ \mathrm{AFD}_{1} & \text { aflatoxin } \mathrm{D}_{1} \\ \mathrm{AFL} & \text { aflatoxicol } \\ \mathrm{AFM} & \\ \mathrm{AFO} & \text { aflatoxin } \mathrm{M}_{1} \\ \mathrm{AFQ} & \text { aflatoxin oxidase enzyme } \\ \mathrm{AFs} & \text { aflatoxin } \mathrm{Q}_{1} \\ \mathrm{AP1} 1 & \text { aflatoxins } \\ & \text { aminopentol } 1\end{array}$




$\begin{array}{ll}\text { CPA } & \text { carboxypeptidase A } \\ \text { CPY } & \text { carboxypeptidase Y } \\ \text { CT } & \text { coated and tough } \\ \text { DDGS } & \text { distiller's grains and soluble } \\ \text { DE } & \text { degrading enzyme } \\ \text { DOE } & \text { Design of experiments } \\ \text { DON } & \text { deoxynivalenol } \\ \text { DPs } & \text { degradation products } \\ \text { EDC } & \text { endocrine disrupting chemical } \\ \text { EFSA } & \text { European Food Safety Authority } \\ \text { ER } & \text { estrogen receptors } \\ \text { FB } 1 & \text { fumonisin } B_{1} \\ \text { GAPs } & \text { Good Agricultural Practices } \\ \text { HFB } & \text { hydrolyzed FB } 1 \\ \text { HR-ESI-MS } & \text { High Resolution electrospray ionization mass spectrometry } \\ \text { HT-2 } & \text { HT-2 toxin } \\ \text { IARC } & \text { International Agency of Research on Cancer } \\ \text { LCs } & \text { laccases } \\ \text { MADE } & \text { Myxobacteria Aflatoxin Degrading Enzyme } \\ \text { MnPs } & \text { Manganese Peroxidases } \\ \text { NIV } & \text { nivalenol } \\ \text { OTA } & \text { ochratoxin A } \\ \text { OT } \alpha & \text { ochratoxin } \alpha \\ \text { Phe } & \text { phenylalanine molecule } \\ \text { Prx } & \text { peroxiredoxin } \\ \text { T-2 } & \text { T-2 toxin } \\ \text { ZEN } & \text { zearalenone } \\ \alpha-Z A L & \alpha \text {-zearalanol } \\ \alpha-Z E L & \alpha \text {-zearalenol } \\ \beta-Z A L & \beta \text {-zearalanol } \\ \beta-Z E L & \\ & \\ \text {-zearalenol }\end{array}$

\section{References and Notes}

1. Bennett, J.W.; Klich, M. Mycotoxins. Clin. Microbiol. Rev. 2003, 16, 497-516. [CrossRef] [PubMed]

2. Logrieco, A.F.; Mulé, G.; Moretti, A.; Bottalico, A. Toxigenic Fusarium species and mycotoxins associated with maize ear rot in Europe. Eur. J. Plant. Pathol. 2002, 108, 597-609.

3. Bryden, W.L. Mycotoxins in the food chain: Human health implications. Asia Pac. J. Clin. Nutr. 2007, 16, 95-101. [PubMed]

4. Shephard, G.S. Impact of mycotoxins on human health in developing countries. Food Addit. Contam. 2008, 25, 146-151.

5. Sharma, R.P. Immunotoxicity of mycotoxins. J. Dairy Sci. 1993, 76, 892-897. [CrossRef]

6. Zain, M.E. Impact of mycotoxins on humans and animals. J. Saudi Chem. Soc. 2011, 15, 129-144. [CrossRef]

7. The International Agency for Research on Cancer (IARC). Some traditional herbal medicines, some mycotoxins, naphthalene and styrene. In IARC Monographs on the Evaluation of Carcinogenic Risks to Humans; World Health Organization: Lyon, France, 2002; Volume 82, pp. 1-556.

8. The International Agency for Research on Cancer (IARC). Some naturally occurring substances: Food items and constituents, heterocyclic aromatic amines and mycotoxins. In IARC Monographs on the Evaluation of Carcinogenic Risks to Humans; World Health Organization: Lyon, France, 1993; Volume 56, pp. 489-521.

9. The International Agency for Research on Cancer (IARC). Chemical agents and related occupations. In IARC Monographs on the Evaluation of Carcinogenic Risks to Humans; World Health Organization: Lyon, France, 2012; Volume 100F, pp. 1-599. 
10. Alassane-Kpembi, I.; Schatzmayr, G.; Taranu, I.; Marin, D.; Puel, O.; Oswald, I.P. Mycotoxins co-contamination: Methodological aspects and biological relevance of combined toxicity studies. Crit. Rev. Microbiol. 2016. [CrossRef] [PubMed]

11. Gelderblom, W.C. Interaction of fumonisin $\mathrm{B}(1)$ and aflatoxin $\mathrm{B}(1)$ in a short-term. Toxicology 2002, 171, 161-173. [CrossRef]

12. Ji, C.; Fan, Y.; Zhao, L. Review on biological degradation of mycotoxins. Anim. Nutr. 2016, 2, 127-133.

13. Gao, Y.N.; Wang, J.Q.; Li, S.L.; Zhang, Y.D.; Zheng, N. Aflatoxin M1 cytotoxicity against human intestinal Caco-2 cells is enhanced in the presence of other mycotoxins. Food Chem. Toxicol. 2016, 96, 79-89. [CrossRef] [PubMed]

14. Roth, A.; Creppy, E.E.; Kane, A.; Bacha, H.; Steyn, P.S.; Roschenthaler, R.; Dirheimer, G. Influence of ochratoxin B on the ochratoxin A inhibition of phenylalanyl-tRNA formation In vitro and protein synthesis in hepatoma tissue culture cells. Toxicol. Lett. 1989, 45, 307-313. [PubMed]

15. Bouslimi, A.; Bouaziz, C.; Ayed-Boussema, I.; Hassen, W.; Bacha, H. Individual and combined effects of ochratoxin A and citrinin on viability and DNA fragmentation in cultured Vero cells and on chromosome aberrations in mice bone marrow cells. Toxicology 2008, 251, 1-7. [CrossRef] [PubMed]

16. Bouslimi, A.; Ouannes, Z.; El Golli, E.; Bouaziz, C.; Hassen, W.; Bacha, H. Cytotoxicity and oxidative damage in kidney cells exposed to the mycotoxins ochratoxin A and citrinin: Individual and combined effects. Toxicol. Mech. Method 2008, 18, 341-349.

17. Klaric, M.S.; Zeljezic, D.; Rumora, L.; Peraica, M.; Pepeljnjak, S.; Domijan, A.M. A potential role of calcium in apoptosis and aberrant chromatin forms in porcine kidney PK15 cells induced by individual and combined ochratoxin A and citrinin. Arch. Toxicol. 2012, 86, 97-107. [CrossRef] [PubMed]

18. Knasmuller, S.; Cavin, C.; Chakraborty, A.; Darroudi, F.; Majer, B.J.; Huber, W.W.; Ehrlich, V.A. Structurally related mycotoxins ochratoxin $\mathrm{A}$, ochratoxin $\mathrm{B}$, and citrinin differ in their genotoxic activities and in their mode of action in human-derived liver (HepG2) cells: Implications for risk assessment. Nutr. Cancer 2004, 50, 190-197. [PubMed]

19. Wu, F. Measuring the economic impacts of Fusarium toxins in animal feed. Anim. Feed Sci. Technol. 2007, 137, 363-374.

20. Commission Regulation 2006/1881/EC of 19 December 2006 Setting Maximum Levels for Certain Contaminants in Food stuffs. Available online: http:/ / eur-lex.europa.eu/legal-content/EN/TXT/PDF/ ?uri=CELEX:32006R1881\&from=en (accessed on 03 November 2016).

21. Commission Recommendation 2013/165/EU of 27 March 2013 on the Presence of T-2 and HT-2 Toxin in Cereals and Cereal Products Text with EEA Relevance. Available online: http:/ / eur-lex.europa.eu/legalcontent/EN/TXT/PDF/?uri=CELEX:32013H0165\&from=EN (accessed on 03 November 2016).

22. Opinion of the Scientific Committee on Food (SCF) on Fusarium Toxins, Part 5: T-2 toxin and HT-2 Toxin. 2001. Available online: https:/ / ec.europa.eu/food/sites/food/files/safety/docs/cs_contaminants_catalogue_ out88_en.pdf (accessed on 03 November 2016).

23. Commission Recommendation 2006/576/EC of 17 August 2006 on the Presence of Deoxynivalenol, Zearalenone, Ochratoxin A, T-2 and HT-2 and Fumonisins in Products intended for Animal Feeding. Available online: http:/ / eur-lex.europa.eu/legal-content/EN/TXT/PDF/?uri=CELEX:32006H0576\&from= EN (accessed on 03 November 2016).

24. Commission Recommendation 2006/583/EC of 17 August 2006 on the Prevention and Reduction of Fusarium Toxins in Cereals and Cereal Products. Available online: http://eur-lex.europa.eu/legal-content/EN/TXT/ PDF/?uri=CELEX:32006H0583\&from=EN (accessed on 03 November 2016).

25. Vanhoutte, I.; Audenaert, K.; De Gelder, L. Biodegradation of Mycotoxins: Tales from Known and Unexplored Worlds. Front. Microbiol. 2016, 7, 561. [CrossRef] [PubMed]

26. Schlüter, O.; Ehlbeck, J.; Hertel, C.; Habermeyer, M.; Roth, A.; Engel, K.H.; Holzhauser, T.; Knorr, D.; Eisenbrand, G. Opinion on the use of plasma processes for treatment of foods. Mol. Nutr. Food Res. 2013, 57, 920-927. [PubMed]

27. Bong, J.P.; Kosuke, T.; Yoshiko, S.K.; Ik-Hwi, K.; Mi-Hee, L.; Dong-Wook, H.; Kie-Hyung, C.; Soon, O.H.; Jong-Chul, P. Degradation of mycotoxins using microwave-induced argon plasma at atmospheric pressure. Surf. Coat. Technol. 2007, 201, 5733-5737.

28. Kriz, P.; Petr, B.; Zbynek, H.; Jaromir, K.; Pavel, O.; Petr, S.; Miroslav, D. Influence of plasma treatment in open air on mycotoxin content and grain nutriments. Plasma Med. 2015, 5, 145-158. [CrossRef] 
29. Herzallah, S.; Al Shawabkeh, K.; Al Fataftah, A. Aflatoxin decontamination of artificially contaminated feeds by sunlight, g-radiation, and microwave heating. J. Appl. Poult. Res. 2008, 17, 515-521.

30. Fanelli, F.; Geisen, R.; Schmidt-Heydt, M.; Logrieco, A.F.; Mulè, G. Light regulation of mycotoxin biosynthesis: New perspectives for food safety. World Mycotoxin J. 2016, 9, 129-146. [CrossRef]

31. Bretz, M.; Beyer, M.; Cramer, B.; Knecht, A.; Humpf, H.-U. Thermal degradation of the Fusarium mycotoxin deoxynivalenol. J. Agric. Food Chem. 2006, 54, 6445-6451. [CrossRef]

32. Park, D.L.; Lee, L.S.; Price, R.L.; Pohland, A.E. Review of the decontamination of aflatoxins by ammoniation: Current status and regulation. J. Assoc. Off. Anal. Chem. 1988, 71, 685-703. [PubMed]

33. Aiko, V.; Edamana, P.; Mehta, A. Decomposition and detoxification of aflatoxin B1 by lactic acid. J. Sci. Food Agric. 2016, 96, 1959-1966. [PubMed]

34. Müller, H.M. Entgiftung von Mykotoxinen: II. Chemische Verfahren und Reaktion mit Inhaltsstoffen von Futtermitteln. Übers Tierernährg. 1983, 11, 47-80.

35. Fouler, S.G.; Trivedi, A.B.; Kitabatake, N. Detoxification of citrinin and ochratoxin a by hydrogen peroxide. J. Assoc. Off. Agric. Chem. 1994, 77, 631-637.

36. Maeba, H.; Takamoto, Y.; Kamimura, M.I.; Miura, T.O. Destruction and detoxification of aflatoxins with ozone. J. Food Sci. 1988, 53, 667-668. [CrossRef]

37. Altug, T.; Youssef, A.E.; Marth, E.H. Degradation of aflatoxin B1 in dried figs by sodium bisulfite with or without heat, ultraviolet energy or hydrogen peroxide. J. Food Prot. 1990, 53, 581-628.

38. Commission Regulation 2015/786/EU Defining Acceptability Criteria for Detoxification Processes Applied to Products Intended for Animal Feed as Provided for in Directive 2002/32/EC of the European Parliament and of the Council. Available online: http:/ / extwprlegs1.fao.org/docs/pdf/eur144560.pdf (accessed on 3 November 2016).

39. Boudergue, C.; Burel, C.; Dragacci, S.; Favrot, M.; Fremy, J.; Massimi, C.; Prigent, P.; Debongnie, P.; Pussemier, L.; Boudra, H.; et al. Review of mycotoxin-detoxifying agents used as feed additives: mode of action, efficacy and feed/food safety. EFSA Support. Publ. 2009, 6. [CrossRef]

40. Hassan, Y.I.; Zhou, T.; Bullerman, L.B. Sourdough lactic acid bacteria as antifungal and mycotoxin-controlling agents. Food Sci. Technol. Int. 2015, 22, 79-90.

41. Hassan, Y.I.; Bullerman, L.B. Cell-surface binding of deoxynivalenol to Lactobacillus paracasei subsp. tolerans isolated from sourdough starter culture. JMBFS 2013, 2, 2323-2325.

42. Böswald, C.; Engelhardt, G.; Vogel, H.; Wallnöfer, P.R. Metabolism of Fusarium mycotoxins zearalenone and deoxynivalenol by yeast strains of technological relevance. Nat. Toxins 1995, 3, 138-144.

43. De Bellis, P.; Tristezza, M.; Haidukowski, M.; Fanelli, F.; Sisto, A.; Mulè, G.; Grieco, F. Biodegradation of ochratoxin A by bacterial strains isolated from vineyard soils. Toxins 2015, 7, 5079-5093. [CrossRef]

44. Sato, I.; Ito, M.; Ishizaka, M.; Ikunaga, Y.; Sato, Y.; Yoshida, S.; Koitabashi, M.; Tsushima, S. Thirteen novel deoxynivalenol-degrading bacteria are classified within two genera with distinct degradation mechanisms. FEMS Microbiol. Lett. 2012, 327, 110-117. [PubMed]

45. He, W.J.; Yuan, Q.S.; Zhang, Y.B.; Guo, M.W.; Gong, A.D.; Zhang, J.B.; Wu, A.B.; Huang, T.; Qu, B.; Li, H.P.; et al. Aerobic de-epoxydation of trichothecene mycotoxins by a soil bacterial consortium isolated using in situ soil enrichment. Toxins 2016, 8, 277.

46. Essigmann, J.M.; Croy, R.G.; Nadzan, A.M.; Busby, W.F., Jr.; Reinhold, V.N.; Büchi, G.; Wogan, G.N. Structural identification of the major DNA adduct formed by aflatoxin B1 In vitro. Proc. Nat. Acad. Sci. USA 1977, 74, 1870-1874. [PubMed]

47. Eaton, D.L.; Gallagher, E.P. Mechanisms of aflatoxin carcinogenesis. Annu. Rev. Pharmacol. Toxicol. 1994, 34, 135-172. [PubMed]

48. Schroeder, T.U.; Zweifel, P.; Sagelsdorff, U.; Friederich, J.; Luthy, C.; Schlatter, J. Ammoniation of aflatoxin-containing corn: Distribution, in vivo covalent deoxyribonucleic acid binding, and mutagenicity of reaction products. Agric. Food Chem. 1985, 33, 311-316. [CrossRef]

49. Méndez-Albores, A.; Arámbula-Villa, G.; Loarca-Piña, M.G.; Castaño-Tostado, E.; Moreno-Martínez, E. Safety and efficacy evaluation of aqueous citric acid to degrade B-aflatoxins in maize. Food Chem. Toxicol. 2005, 43, 233-238. [PubMed]

50. Motomura, M.; Toyomasu, T.; Mizuno, K.; Shinozawa, T. Purification and characterization of an aflatoxin degradation enzyme from Pleurotus ostreatus. Microbiol. Res. 2003, 158, 237-242. [PubMed] 
51. Liu, D.L.; Yao, D.S.; Liang, R.; Ma, L.; Cheng, W.Q.; Gu, L.Q. Detoxifcation of aflatoxin B1 by enzymes isolated from Armillariella tabescens. Food Chem. Toxicol. 1998, 36, 563-574.

52. Chitrangada, D.; Mishra, H.N. In vitro degradation of aflatoxin B1 by horseradish peroxidase. Food Chem. 2000, 68, 309-313.

53. Alberts, J.F.; Gelderblom, W.C.; Botha, A.; van Zyl, W.H. Degradation of aflatoxin B(1) by fungal laccase enzymes. Int. J. Food Microbiol. 2009, 30, 47-52.

54. Novozymes A/S. Detoxification of Aflatoxin in Feed Products. World Patent 2009109607, 5 March 2009.

55. Taylor, M.C.; Jackson, C.J.; Tattersall, D.B.; French, N.; Peat, T.S.; Newman, J.; Briggs, L.J.; Lapalikar, G.V.; Campbell, P.M.; Scott, C.; et al. Identification and characterization of two families of F420H2-dependent reductases from Mycobacteria that catalyse aflatoxin degradation. Mol. Microbiol. 2010, 78, 561-575. [PubMed]

56. Yehia, R.S. Aflatoxin detoxification by manganese peroxidase purified from Pleurotus ostreatus. Braz. J. Microbiol. 2014, 45, 127-133. [PubMed]

57. Zhao, L.H.; Guan, S.; Gao, X.; Ma, Q.G.; Lei, Y.P.; Bai, X.M.; Ji, C. Preparation, purification and characteristics of an aflatoxin degradation enzyme from Myxococcus fulvus ANSM068. J. Appl. Microbiol. 2011, 110, 147-155. [CrossRef]

58. Loi, M.; Fanelli, F.; Zucca, P.; Liuzzi, V.C.; Quintieri, L.; Cimmarusti, M.T.; Monaci, L.; Haidukovski, M.; Logrieco, A.F.; Sanjust, E.; et al. Aflatoxin $\mathrm{B}_{1}$ and $\mathrm{M}_{1}$ degradation by Lac2 from Pleurotus pulmonarius and redox mediators. Toxins 2016, 8, 245. [CrossRef] [PubMed]

59. Loi, M.; Quintieri, L.; Liuzzi, V.C.; Haidukovski, M.; Logrieco, A.F.; Sanjust, E.; Fanelli, F.; Mulè, G. Aflatoxin $\mathrm{M}_{1}$ removal and biotechnological application of a laccase from Pleurotus eryngii for milk safety. Scienza e Tecnica Lattiero Casearia. In press.

60. Cao, H.; Liu, D.; Mo, X.; Xie, C.; Yao, D. A fungal enzyme with the ability of aflatoxin B1 conversion: Purification and ESI-MS/MS identification. Microbiol. Res. 2011, 166, 475-483. [CrossRef] [PubMed]

61. Liu, D.L.; Ma, L.; Gu, L.Q.; Liang, R.; Yao, D.S.; Chen, W.Q. Armillariella tabescens enzymatic detoxification of aflatoxin B1. Part III. Immobilized enzymatic detoxification. Ann. N. Y. Acad. Sci. 1998, 864, 592-599. [PubMed]

62. Wu, Y.Z.; Lu, F.P.; Jiang, H.L.; Tan, C.P.; Yao, D.S.; Xie, C.F.; Liu, D.L. The furofuran-ring selectivity, hydrogen peroxide-production and low $\mathrm{K}_{\mathrm{m}}$ value are the three elements for highly effective detoxification of aflatoxin oxidase. Food Chem. Toxicol. 2015, 76, 125-131.

63. Wang, J.; Ogata, M.; Hirai, H.; Kawagishi, H. Detoxification of aflatoxin B1 by manganese peroxidase from the white-rot fungus Phanerochaete sordida YK-624. FEMS Microbiol. Lett. 2011, 314, 164-169. [CrossRef] [PubMed]

64. Chitrangada, D.; Mishra, H.N. In vitro degradation of aflatoxin B1 in groundnut (Arachis hypogea) meal by horseradish peroxidase. Lebensm. Wiss. Technol. 2000, 33, 308-312.

65. Viswanath, B.; Rajesh, B.; Janardhan, A.; Kumar, A.P.; Narasimha, G. Fungal laccases and their applications in bioremediation. Enzyme Res. 2014, 2014, 1-21.

66. Banu, I.; Lupu, A.; Aprodu, I. Degradation of zearalenone by laccase enzyme. Sci. Study Res. 2013, 14, 79-84.

67. Novozymes A/S. Detoxification of Aflatoxin in Feed Products. European Patent 2252163, 5 March 2009.

68. Margot, J.; Bennati-Granier, C.; Maillard, J.; Blánquez, P.; Barry, D.A.; Holliger, C. Bacterial versus fungal laccase: Potential for micropollutant degradation. AMB Express 2013, 3, 63-77. [CrossRef]

69. Guan, S.; Zhao, L.; Ma, Q.; Zhou, T.; Wang, N.; Hu, X.; Ji, C. In vitro efficacy of Myxococcus fulvus ANSM068 to biotransform aflatoxin $\mathrm{B}_{1}$. Int. J. Mol. Sci. 2010, 11, 4063-4079.

70. Dirheimer, G.; Creppy, E.E. Mechanism of action of ochratoxin A. IARC Sci. Publ. 1991, 115, 171-186.

71. Pfohl-Leszkowicz, A.; Manderville, R.A. An update on direct genotoxicity as molecular mechanism of ochratoxin A carcinogenicity. Chem. Res. Toxicol. 2012, 25, 252-262. [PubMed]

72. Vettorazzi, A.; van Delft, J.; López de Cerain, A. A review on ochratoxin A transcriptomic studies. Food Chem. Toxicol. 2013, 59, 766-783. [PubMed]

73. Kőszegi, T.; Poór, M. Ochratoxin A: Molecular interactions, mechanisms of toxicity and prevention at the molecular Level. Toxins 2016, 8, 111. [CrossRef] [PubMed]

74. Abrunhosa, L.; Paterson, R.R.; Venâncio, A. Biodegradation of Ochratoxin A for Food and Feed Decontamination. Toxins 2010, 2, 1078-1099. [CrossRef]

75. Pitout, M.J. The hydrolysis of Ochratoxin A by some proteolytic enzymes. Biochem. Pharmacol. 1969, 18, 485-491. [PubMed] 
76. Dridi, F.; Marrakchi, M.; Gargouri, M.; Saulnier, J.; Jaffrezic-Renault, N.; Lagarde, F. Comparison of carboxypeptidase $\mathrm{Y}$ and thermolysin for ochratoxin A electrochemical biosensing. Anal. Methods 2015, 7, 8954-8960.

77. Stander, M.A.; Bornscheuer, U.T.; Henke, E.; Steyn, P.S. Screening of commercial hydrolases for the degradation of ochratoxin A. J. Agric. Food Chem. 2000, 48, 5736-5739. [PubMed]

78. Abrunhosa, L.; Santos, L.; Venâncio, A. Degradation of ochratoxin A by proteases and by a crude enzyme of Aspergillus niger. Food Biotechnol. 2006, 20, 231-242.

79. Danisco A/S. Food Additive Comprising an Amidase for Detoxifying Ochratoxin. World Patent 2012032472, 6 September 2011.

80. Heinl, S.; Hartinger, D.; Moll, W.D.; Schatzmayr, G.; Grabherr, R. Identification of a fumonisin B1 degrading gene cluster in Sphingomonas sp. MTA144. New Biotechnol. 2009, 25, S61-S62. [CrossRef]

81. Wang, E.; Norred, W.P.; Bacon, C.W.; Riley, R.T.; Merrill, A.H., Jr. Inhibition of sphingolipid biosynthesis by fumonisins: Implications for diseases associated with Fusarium moniliforme. J. Biol. Chem. 1991, 266, 14486-14490. [PubMed]

82. Merrill, A.H.; Wang, E.; Vales, T.R.; Smith, E.R.; Schroeder, J.J.; Menaldino, D.S.; Alexander, C.; Crane, H.M.; Xia, J.; Liotta, D.C.; et al. Fumonisin toxicity and sphingolipid biosynthesis. Adv. Exp. Med. Biol. 1996, 392, 297-306. [PubMed]

83. Soriano, J.M.; González, L.; Catala, A.I. Mechanism of action of sphingolipids and their metabolites in the toxicity of fumonisin B1. Progr. Lipid Res. 2005, 44, 345-356. [CrossRef]

84. Rheeder, J.P.; Marasas, W.F.O.; Vismer, H.F. Production of fumonisin analogs by Fusarium species. Appl. Environ. Microbiol. 2002, 68, 2101-2105. [PubMed]

85. Aly, S.E.; Abdel-Galil, M.M.; Abdel-Wahhab, M.A. Application of adsorbent agents technology in the removal of aflatoxin B1 and fumonisin B1 from malt extract. Food Chem. Toxicol. 2004, 42, 1825-1831.

86. Robinson, A.; Johnson, N.M.; Strey, A.; Taylor, J.F.; Marroquin-Cardona, A.; Mitchell, N.J.; Afriyie-Gyawu, E.; Ankrah, N.A.; Williams, J.H.; Wang, J.S.; et al. Calcium montmorillonite clay reduces urinary biomarkers of fumonisin B1 exposure in rats and humans. Food Addit. Contam. 2012, 29, 809-818.

87. Pioneer Hi-Bred International, Inc. Fumonisin detoxification compositions and methods. U.S. Patent 5792931, 7 June 1995.

88. Duvick, J. Prospects for reducing fumonisin contamination of maize through genetic modification. Environ. Health Persp. 2001, 109, 337-342. [CrossRef]

89. Pioneer Hi-Bred International, Inc. Fumonisin-Detoxifying Enzymes. World Patent 1996006175, 11 August 1995.

90. Duvick, J.; Rood, T.; Maddox, J.; Gilliam, J. Detoxification of mycotoxins in planta as a strategy for improving grain quality and disease resistance: Identification of fumonisin-degrading microbes from maize. In Molecular Genetics of Host-Specific Toxins in Plant Disease; Kohmoto, K., Yoder, O., Eds.; Kluwer Academic Publishers: Dordrecht, The Netherlands, 1998; pp. 369-381.

91. Scientific Opinion on the safety and efficacy of fumonisin esterase (FUMzyme ${ }^{\circledR}$ ) as a technological feed additive for pigs. EFSA J. 2014, 12, 3667.

92. Täubel, M. Isolierung und Charakterisierung von Mikroorganismen zur Biologischen Inaktivierung von Fumonisinen. Ph.D. Thesis, University of Natural Resources and Applied Life Sciences, Vienna, Austria, 2005.

93. Hartinger, D.; Schwartz, H.; Hametner, C.; Schatzmayr, G.; Haltrich, D.; Moll, W.D. Enzyme characteristics of aminotransferase FumI of Sphingopyxis sp. MTA144 for deamination of hydrolyzed fumonisin B1. Appl. Microbiol. Biotechnol. 2011, 91, 757-768. [CrossRef] [PubMed]

94. Heinl, S.; Hartingerb, D.; Thamhesl, M.; Schatzmayrb, G.; Moll, W.D.; Grabherra, R. An aminotransferase from bacterium AtrichotheceneC 55552 deaminates hydrolyzed fumonisin B1. Biodegradation 2011, 22, 25-30. [CrossRef] [PubMed]

95. Method for the Production of an Additive for the Enzymatic Decomposition of Mycotoxins, Additive, and Use Thereof. U.S. Patent 8,703,460, 2008.

96. Ueno, Y. Trichothecenes. In Chemical, Biological and Toxicological Aspects; Elsevier Scientific Publishers: Amsterdam, The Netherlands, 1983.

97. Zöllner, P.; Mayer-Helm, B. Trace mycotoxin analysis in complex biological and food matrices by liquid chromatography-atmospheric pressure ionisation mass spectrometry. J. Chromatogr. A 2006, 1136, 123-169. [CrossRef] [PubMed] 
98. Grove, J.F. The trichothecenes and their biosynthesis. Prog. Chem. Org. Nat. Prod. 2007, 88, 63-130.

99. Rocha, O.; Ansari, K.; Doohan, F.M. Effects of trichothecene mycotoxins on eukaryotic cells: A review. Food Addit. Contam. 2005, 22, 369-378. [CrossRef]

100. Schuhmacher-Wolz, U.; Heine, K.; Schneider, K. Report on Toxicity Data on Trichothecene Mycotoxins HT-2 and T-2 Toxins. CT/EFSA/CONTAM/2010/03. Available online: http://www.efsa.europa.eu/en/scdocs/ doc/65e.pdf (accessed on 10 November 2016).

101. Miller, J.D. Aspects of the ecology of Fusarium toxins in cereals. Adv. Exp. Med. Biol. 2002, 504, $19-27$.

102. World Health Organization. WHO Food Additives Series: 47. Safety Evaluation of Certain Mycotoxins in Food. Prepared by the Fifty-Sixth Meeting of the Joint FAO/WHO Expert Committee on Food Additives (JECFA). 2001. Available online: http:/ / www.inchem.org/documents/jecfa/jecmono/v47je01.htm (accessed on 10 November 2016).

103. Pestka, J.J. Deoxynivalenol: Mechanisms of action, human exposure, and toxicological relevance. Arch. Toxicol. 2010, 84, 663-679. [CrossRef] [PubMed]

104. Thompson, W.L.; Wannemacher, R.W., Jr. Structure-function relationship of 12,13-epoxytrichothecene mycotoxins in cell culture: Comparison of whole animal lethality. Toxicon 1986, 24, 985-994. [CrossRef]

105. Cundliffe, E.; Cannon, M.; Davies, J. Mechanism of inhibition of eukaryotic protein synthesis by trichothecene fungal toxins. Proc. Natl. Acad. Sci. USA 1974, 71, 30-34. [PubMed]

106. Cundliffe, E.; Davies, J.E. Inhibition of initiation, elongation, and termination of eukaryotic protein synthesis by trichothecene fungal toxins. Antimicrob. Agents Chemother. 1977, 11, 491-499. [CrossRef] [PubMed]

107. Sudakin, D.L. Trichothecenes in the environment: Relevance to human health. Toxicol. Lett. 2003, 20, 97-107.

108. Karlovsky, P. Biological detoxification of the mycotoxin deoxynivalenol and its use in genetically engineered crops and feed additives. Appl. Microbiol. Biotechnol. 2011, 91, 491-504. [PubMed]

109. Hassan, Y.I.; Zhu, H.; Zhu, Y.; Zhou, T. Beyond ribosomal binding-the increased polarity and aberrant molecular interactions of 3-epi-deoxynivalenol. Toxins 2016, 8, 261.

110. He, J.W.; Hassan, Y.I.; Perilla, N.; Li, X.Z.; Boland, G.J.; Zhou, T. Bacterial epimerization as a route for deoxynivalenol detoxification: The influence of growth and environmental conditions. Front. Microbiol. 2016, 7, 572. [CrossRef] [PubMed]

111. He, J.; Zhou, T.; Young, J.C.; Boland, G.J.; Scott, P.M. Chemical and biological transformations for detoxification of trichothecene mycotoxins in human and animal food chains: A review. Trend Food Sci. Technol. 2010, 21, 67-76. [CrossRef]

112. Ito, M.; Sato, I.; Ishizaka, M.; Yoshida, S.; Koitabashi, M.; Yoshida, S.; Tsushima, S. Bacterial cytochrome P450 system catabolizing the Fusarium toxin deoxynivalenol. Appl. Environ. Microbiol. 2013, 79, 1619-1628. [CrossRef] [PubMed]

113. Poppenberger, B.; Berthiller, F.; Lucyshyn, D.; Sieberer, T.; Schuhmacher, R.; Krska, R.; Kuchler, K.; Glössl, J.; Luschnig, C.; Adam, G. Detoxification of the Fusarium mycotoxin deoxynivalenol by a UDP-glucosyltransferase from Arabidopsis thaliana. J. Biol. Chem. 2003, 278, 47905-47914. [CrossRef] [PubMed]

114. Pierron, A.; Mimoun, S.; Murate, L.S.; Loiseau, N.; Lippi, Y.; Bracarense, A.P.; Schatzmayr, G.; He, J.W.; Zhou, T.; Moll, W.D.; et al. Microbial biotransformation of DON: Molecular basis for reduced toxicity. Sci. Rep. 2016, 6, 29105.

115. Zinedine, A.; Soriano, J.M.; Molto, J.C.; Manes, J. Review on the toxicity, occurrence, metabolism, detoxification, regulations and intake of zearalenone: An oestrogenic mycotoxin. Food Chem. Toxicol. 2007, 45, 1-18. [CrossRef] [PubMed]

116. Shier, W.T.; Shier, A.C.; Xie, W.; Mirocha, C.J. Structure-activity relationships for human estrogenic activity in zearalenone mycotoxins. Toxicon 2001, 39, 1435-1438. [CrossRef]

117. Takahashi-Ando, N.; Kimura, M.; Kakeya, H.; Osada, H.; Yamaguchi, I. A novel lactonohydrolase responsible for the detoxification of zearalenone: Enzyme purification and gene cloning. Biochem. J. 2002, 365, 1-6.

118. Takahashi-Ando, N.; Tokai, T.; Hamamoto, H.; Yamaguchi, I.; Kimura, M. Efficient decontamination of zearalenone, the mycotoxin of cereal pathogen, by transgenic yeasts through the expression of a synthetic lactonohydrolase gene. Appl. Microbiol. Biotechnol. 2005, 67, 838-844. [PubMed]

119. Riken. Zearalenone-Detoxifying Enzyme Gene and Transformant Having the Gene Transferred Thereinto. World Patent 2003080842, 25 March 2003.

120. Novozymes A/S. Detoxification of Feed Products. World Patent 2009109607, 5 March 2009. 
121. Yu, Y.; Wu, H.; Tang, Y.; Qiu, L. Cloning, expression of a peroxiredoxin gene from Acinetobacter sp. SM04 and characterization of its recombinant protein for zearalenone detoxification. Microbiol. Res. 2012, 167, 121-126. [PubMed]

122. Tang, Y.; Xiao, J.; Chen, Y.; Yu, Y.; Xiao, X.; Yu, Y.; Wu, H. Secretory expression and characterization of a novel peroxiredoxin for zearalenone detoxification in Saccharomyces cerevisiae. Microbiol. Res. 2013, 168, 6-11.

123. Altalhi, A.D.; El-Deeb, B. Localization of zearalenone detoxification gene(s) in pZEA-1 plasmid of Pseudomonas putida ZEA-1 and expressed in Escherichia coli. J. Hazard. Mater. 2009, 161, 1166-1172. [CrossRef]

124. Patel, A.K.; Singhania, R.R.; Pandey, A. Novel enzymatic processes applied to the food industry. Curr. Opin. Food Sci. 2016, 7, 64-72. [CrossRef]

125. Sun, Y.; Cheng, J. Hydrolysis of lignocellulosic materials for ethanol production: A review. Biores. Technol. 2002, 83, 1-11.

126. Berthiller, F.; Crews, C.; Dall'Asta, C.; Saeger, S.D.; Haesaert, G.; Karlovsky, P.; Oswald, I.P.; Seefelder, W.; Speijers, G.; Stroka, J. Masked mycotoxins: A review. Mol. Nutr. Food Res. 2013, 57, 165-186. [CrossRef]

127. Baldino, L.; Cardea, S.; Reverchon, E. Supercritical assisted enzymatic membranes preparation, for active packaging applications. J. Memb. Sci. 2014, 453, 409-418.

128. Regulation (EC) No 1332/2008 of the European Parliament and of the Council of 16 December 2008 on food enzymes and amending Council Directive 83/417/EEC, Council Regulation (EC) No 1493/1999, Directive 2000/13/EC, Council Directive 2001/112/EC and Regulation (EC) No 258/97.

129. Osma, J.F.; Toca-Herrera, J.L.; Rodriguez-Couto, S. Uses of Laccases in the Food Industry. Enzym. Res. 2010, 2010, 918761. [CrossRef]

130. Gassara-Chatti, F.; Brar, S.K.; Ajila, C.M.; Verma, M.; Tyagi, R.D.; Valero, J.R. Encapsulation of ligninolytic enzymes and its application in clarification of juice. Food Chem. 2013, 137, 18-24.

131. Lettera, V.; Pezzella, C.; Cicatiello, P.; Piscitelli, A.; Giacobelli, V.G.; Galano, E.; Amoresano, A.; Sannia, G. Efficient immobilization of a fungal laccase and its exploitation in fruit juice clarification. Food Chem. 2016, 196, 1272-1278.

132. Clickner, F.H.; Follwell, E.H. Application of 'Protozyme' (Aspergillus orizae) to poultry feeding. Poult. Sci. 1925, 5, 241-247. [CrossRef]

133. Menezes-Blackburn, D.; Greiner, R. Enzymes used in animal feed: Leading technologies and forthcoming developments. In Functional Polymers in Food Science: From Technology to Biology, Volume 2: Food Processing; Cirillo, G., Spizzirri, U.G., Iemma, F., Eds.; Wiley: Hoboken, NJ, USA, 2015.

134. Regulation (EC) No 1831/2003 of the European Parliament and of the Council of 22 September 2003 on Additives for Use in Animal Nutrition. Available online: http:/ / eur-lex.europa.eu/legal-content/EN/TXT/ PDF/?uri=CELEX:32003R1831\&from=EN (accessed on 17 November 2016).

135. Beaman, K.R.; Lilly, K.G.S.; Gehring, C.K.; Turk, P.J.; Moritz, J.S. Influence of pelleting on the efficacy of an exogenous enzyme cocktail using broiler performance and metabolism. J. Appl. Poult. Res. 2012, 21, 744-775. [CrossRef]

136. Novo Nordisk A/S. Enzyme-Containing Granules and Process for the Production Thereof. World Patent 1997039116, 14 April 1997.

137. Xiros, C.; Topakas, E.; Christakopoulos, P. Hydrolysis and fermentation for cellulosic ethanol production. WIREs Energy Environ. 2013, 2, 633-654. [CrossRef]

138. Kudanga, T.; Le Roes-Hill, M. Laccase applications in biofuels production: Current status and future prospects. Appl. Microbiol. Biotechnol. 2014, 98, 6525-6542.

139. Jurado, M.; Prieto, A.; Martínez-Alcalá, A.; Martínez, A.T.; Martínez, M.J. Laccase detoxification of steam-exploded wheat straw for second generation bioethanol. Bioresour. Technol. 2009, 100, 6378-6384. [PubMed]

140. Christy, P.M.; Divya, D.; Gopinath, L.R. A review on anaerobic decomposition and enhancement of biogas production through enzymes and microorganisms. Renew. Sustain. Energy Rev. 2014, 34, 167-173. [CrossRef]

141. Parawira, W. Enzyme research and applications in biotechnological intensification of biogas production. Crit. Rev. Biotechnol. 2012, 32, 172-186.

142. Effenberger, M.; Lebuhn, M.; Gronauer, A. Fermentermanagement-Stabiler Prozess bei NawaRo-Anlagen. Biogas Wandel 2007, 16, 99-105.

143. Storm, I.M.L.D.; Sørensen, J.L.; Rasmussen, R.R.; Nielsen, K.F.; Thrane, U. Mycotoxins in silage. Stewart Posthar. Rev. 2008, 1-12. [CrossRef] 
144. Salati, S.; D'Imporzano, G.; Panseri, S.; Pasquale, E.; Adani, F. Degradation of aflatoxin b1 during anaerobic digestion and its effect on process stability. Int. Biodeter. Biodegrad. 2014, 94, 19-23.

145. De Gelder, L.; Audenaert, K.; Willems, B.; Schelfhout, K.; De Saeger, S.; De Boevre, M. Biodegradability of Mycotoxins during Anaerobic Digestion, Abstract in De Saeger, S.; Audenaert, K.; Croubels, S. Report from the 5th International Symposium on Mycotoxins and Toxigenic Moulds: Challenges and Perspectives (MYTOX) Held in Ghent, Belgium, May 2016. Toxins 2016, 8, 146.

146. Rintala, J.; Ahring, B.K. A two-stage thermophilic anaerobic process for the treatment of source sorted household solid waste. Biotechnol. Lett. 1994, 16, 1097-1102. [CrossRef]

147. Binner, R.; Menath, V.; Huber, H.; Thomm, M.; Bischof, F.; Schmack, D.; Reuter, M. Comparative study of stability and half-life of enzymes and enzyme aggregates implemented in anaerobic biogas processes. Biomass Convers. Biorefin. 2011, 1, 1-8. [CrossRef]

148. Dzuman, Z.; Stranska-Zachariasova, M.; Vaclavikova, M.; Tomaniova, M.; Veprikova, Z.; Slavikova, P.; Hajslova, J. Fate of Free and conjugated mycotoxins within the production of distiller's dried grains with solubles (DDGS). J. Agric. Food Chem. 2016, 64, 5085-5092. [CrossRef]

149. Wu, F.; Munkvold, G. Mycotoxins in ethanol co-products: Modeling economic impacts on the livestock industry and management strategies. J. Agric. Food Chem. 2008, 56, 3900-3911.

150. Nathanail, A.V.; Gibson, B.; Han, L.; Peltonen, K.; Ollilainen, V.; Jestoi, M.; Laitila, A. The lager yeast Saccharomyces pastorianus removes and transforms Fusarium trichothecene mycotoxins during fermentation of brewer's wort. Food Chem. 2016, 203, 448-455. [CrossRef]

151. Boeira, L.; Bryce, J.; Stewart, G.; Flannigan, B. Inhibitory effect of Fusarium mycotoxins on growth of brewing yeasts. 1 zearalenone and fumonisin B1. J. Inst. Brew. 1999, 105, 366-375. [CrossRef]

152. Commission Regulation (EU) No 68/2013 of 16 January 2013 on the Catalogue of Feed Materials. Available online: http:/ / eur-lex.europa.eu/legal-content/EN/TXT/PDF/?uri=CELEX:32013R0068\&from= EN (accessed on 17 November 2016).

153. Feeds Regulations (SOR/83-593), Feeds act. Government of Canada, 1983. Available online: http:/ /lawslois.justice.gc.ca/PDF/SOR-83-593.pdf (accessed on 17 November 2016).

154. Code of Federal Regulations (CFR), Title 21, Sections 573 Food Additives Permitted in Feed and Drinking Water of Animals. Available online: https://www.accessdata.fda.gov/scripts/cdrh/cfdocs/ cfcfr/CFRSearch.cfm?CFRPart=573\&showFR=1 (accessed on 17 November 2016).

155. Regulation (EC) No 1069/2009 of the European Parliament and of the Council of 21 October 2009 Laying down Health Rules as Regards Animal by-Products and Derived Products Not Intended for Human Consumption and Repealing Regulation (EC) No 1774/2002 (Animal by-Products Regulation). Available online: http:/ / eur-lex.europa.eu/legal-content/EN/TXT/PDF/?uri=CELEX:32009R1069\&from= EN (accessed on 17 November 2016).

156. Sosa, M.A.; Chovau, S.; Van der Bruggen, B.; Espinosa, J. Ethanol production from corn contaminated with fumonisins: A preliminary economic analysis including novel processing alternatives. Ind. Eng. Chem. Res. 2013, 52, 7504-7513. [CrossRef]

157. Liu, K. Chemical Composition of Distillers Grains, a Review. J. Agric. Food Chem. 2011, 59, $1508-1526$. [CrossRef]

158. Zhejiang University. A Method for Reducing the Content of Patulin in Apple Juice Concentrate. Chinese Patent 103859016, 26 February 2014.

159. Pioneer Hi-Bred International, Inc. Beauvericin Detoxification Method Using Bacteria. U.S. Patent 6126934, 29 January 1998.

160. Pioneer Hi-Bred International, Inc. Moniliformin detoxification compositions and methods. Canadian Patent 2272554, 12 November 1997.

161. Liuzzi, V.C.; Fanelli, F.; Tristezza, M.; Haidukowski, M.; Picardi, E.; Manzari, C.; Lionetti, C.; Grieco, F.; Logrieco, A.F.; Thon, M.R.; et al. Transcriptional analysis of Acinetobacter sp. neg1 capable of degrading ochratoxin A. Front. Microbiol. 2017, 7, 2162.

162. Fanelli, F.; Chiara, M.; Liuzzi, V.C.; Haidukowski, M.; Tristezza, M.; Manzari, C.; D’Erchia, A.M.; Pesole, G.; Horner, D.S.; Mulè, G. Draft genome sequence of Acinetobacter sp. neg1 capable of degrading ochratoxin A. FEMS Microbiol. Lett. 2015, 362, 7. [CrossRef] 
163. USDA Economic Research Service. Adoption of Genetically Engineered Crops in the U.S. USDA: Washington, DC, USA, 2011. Available online: https://www.ers.usda.gov/data-products/adoption-of-geneticallyengineered-crops-in-the-us.aspx (accessed on 17 November 2016).

164. Hohn, T.M.; Peters, C.; Salmeron, J. Trichothecene-Resistant Transgenic Plants. U.S. Patent 20020162136, 12 February 2002.

165. Kimura, M.; Kaneko, I.; Komiyama, M.; Takatsuki, A.; Koshino, H.; Yoneyama, K.; Yamaguchi, I. Trichothecene 3-O-acetyltransferase protects both the producing organism and transformed yeast from related mycotoxins. J. Biol. Chem. 1998, 273, 1654-1661.

166. Kimura, M.; Shingu, Y.; Yoneyama, K.; Yamaguchi, I. Features of Tri101, the trichothecene 3-Oacetyltransferase gene, related to the self-defense mechanism in Fusarium graminearum. Biosci. Biotech. Bioch. 1998, 62, 1033-1036. [CrossRef]

(C) 2017 by the authors. Licensee MDPI, Basel, Switzerland. This article is an open access article distributed under the terms and conditions of the Creative Commons Attribution (CC BY) license (http://creativecommons.org/licenses/by/4.0/). 